NBER WORKING PAPER SERIES

\title{
CONSUMER RESPONSE TO TAX REBATES
}

\author{
Matthew D. Shapiro \\ Joel Slemrod \\ Working Paper 8672 \\ http://www.nber.org/papers/w8672 \\ NATIONAL BUREAU OF ECONOMIC RESEARCH \\ 1050 Massachusetts Avenue \\ Cambridge, MA 02138 \\ December 2001
}

The authors gratefully acknowledge comments on the survey design from Richard Curtin, participants at the University of Michigan summer workshop on behavioral economics, and members of the staffs of the Survey Research Center, the Federal Reserve Board, and the U.S. Department of the Treasury. They also acknowledge comments on earlier drafts from Jonathan Parker, N. Gregory Mankiw, and Chang-Tai Hsieh and financial support of the Survey Research Center and the Office of Tax Policy Research in conducting the survey. This revision incorporates data collected through October 2001 and replaces the preliminary version based on data through September 2001. Shapiro is Professor of Economics and Senior Research Scientist of the Survey Research Center, University of Michigan. Slemrod is Professor of Economics and Professor of Business Economics and Public Policy, University of Michigan. Both are Research Associates of the National Bureau of Economic Research. The views expressed herein are those of the authors and not necessarily those of the National Bureau of Economic Research.

(C) 2001 by Matthew D. Shapiro and Joel Slemrod. All rights reserved. Short sections of text, not to exceed two paragraphs, may be quoted without explicit permission provided that full credit, including $(\mathbb{C}$ notice, is given to the source. 
Consumer Response to Tax Rebates

Matthew D. Shapiro and Joel Slemrod

NBER Working Paper No. 8672

December 2001

JEL No. E21, E65, C42

\begin{abstract}
Many households received income tax rebates in 2001 of $\$ 300$ or $\$ 600$. These rebates represented advance payments of the tax cut from the new 10 percent tax bracket. Based on a survey of a representative sample of households, this paper finds that only 22 percent of households receiving the rebate would spent it. Instead, they would either save it or use it to pay off debt. This very low rate of spending represents a striking break with past behavior, which would have suggested a much higher rate of spending. The low spending rate implies that the tax rebate provided a very limited stimulus to aggregate demand.
\end{abstract}

Matthew D. Shapiro

Department of Economics and Survey Research Center

University of Michigan

Ann Arbor, MI 48109-1220

and NBER

(734) 764-5419

shapiro@umich.edu
Joel Slemrod

Department of Economics and Business School

University of Michigan

Ann Arbor, MI 48109-1234

and NBER

(734) 936-3914

jslemrod@umich.edu 
Standard economic theory has specific predictions about how consumers will respond to changes in disposable income. For example, the response of consumers will depend on whether the changes are expected or unexpected, and on whether they are temporary or permanent. When the change in disposable income arises from a change in tax policy, the theory predicts that consumer responses also depend on whether they perceive the changes in taxes to be accompanied by changes in government spending.

This paper advances survey techniques to estimate the marginal propensity to consume. In July through September 2001, many households received tax rebates of $\$ 300$ or $\$ 600$. These rebates were advance payments of the tax reduction associated with the creation of the new, 10 percent income tax bracket. We conducted a survey of a representative sample of U.S. households during August, September, and October 2001 to determine how the receipt of the rebate checks would change behavior. We find that only 22 percent of those receiving the rebate reported that it would lead them to mostly increase spending. This propensity to spend is remarkably low, both from a theoretical prospective and when compared to previous estimates.

- The propensity to consume from a permanent tax cut should, in the standard model, be close to one. Moreover, households that are liquidity constrained would consume at a high rate even if they perceive the tax cut to be less than permanent.

- Previous estimates of the propensity to consume, either from aggregate or individual data, generally point to a much higher propensity to consume. 
Hence, the evidence from the consumer response to the 2001 tax rebate represents a sharp break with previous evidence. The time-series evidence suggests a propensity to consume of about one-half even from expected changes in income. The cross-sectional evidence is more varied, but even for changes in income where theory would suggest a propensity to consume of close to zero, the evidence typically suggests a high propensity to consume.

The lower propensity to consume we find cannot be attributed to our survey methodology. In 1992, we fielded a similar survey question to measure the propensity to consume from the 1992 changes in income tax withholding. Both the 1992 and 2001 survey questions were included as modules on the University of Michigan Survey Research Center's monthly Survey of Consumers, so the procedures for drawing the sample were the same in both surveys. For the 1992 withholding change, we found that over forty percent of households would spend the extra current income from the reduction in withholding, despite the fact that the increase in take-home pay would be offset by either a lower tax refund or higher final payment. While that behavior is inconsistent with unconstrained optimization, it is quite consistent with the broad range of evidence that a high fraction of income goes to households who act myopically or liquidity constrained with respect to changes in income. Because the methodology used to study the 2001 rebate so closely mirrors that of the 1992 study, the surprising results of the 2001 study appear to represent a genuine departure from past behavior and are not an artifact of our methodology or the specific details of the survey.

Whether consumers behave according to the standard theory has substantial implications for both the understanding of economic fluctuations and for predictions 
about the likely impact of changes in government policy. If consumers are foresighted and unconstrained, their spending behavior may either damp or magnify the response to a current shock to income depending on the relationship of the income shock to changes in future income.

There are a number of reasons why households might not increase spending from a putatively permanent tax rebate. They might not believe that it is permanent, or they might believe that it would be offset by some other government action (e.g., a cut in a benefit or a future increase of another tax). In designing the survey, we included questions to shed light on these hypotheses. Moreover, there is a substantial degree of heterogeneity in consumer behavior. Again, the survey is designed to elicit information to systematically account for this heterogeneity. A strength of the survey methodology is that it allows direct tests of hypotheses that might account for the behavior.

The present study is intended to extend our understanding of consumer response to fiscal interventions. One goal is simply to assess the extent to which the rebate induced consumers to spend more than they otherwise would have, on what kinds of goods, and over what time periods. An equally important objective is to test various hypotheses about what motivates the variation in behavioral response to the rebate, and to discriminate among reasonable alternative explanations. For example, a taxpayer who does not increase spending upon receiving the check may do so because of a Ricardian belief that it signals no increase in their well-being. Alternatively, someone who increases spending upon receiving the check may do so because he or she is liquidity constrained or because the new tax law, of which the rebate is a small part, implies a large increase in permanent after-tax income. 
The plan of the remainder of the paper is as follows. Section I describes the change in tax policy in 2001. Section II gives details of the survey. Section III presents the results. Section IV surveys the literature on propensity to consume in the context of these results. Section V presents our conclusions.

\section{The Policy}

On May 25, 2001, the congressional conference committee approved the Economic Growth and Tax Relief Reconciliation Act of 2001. President George W. Bush signed the bill into law on June 7, 2001. Under the bill, taxpayers were entitled to a credit in tax year 2001 up to $\$ 300$ for single individuals and up to $\$ 600$ in the case of a married couple filing a joint return. Most taxpayers received this credit in the form of a check issued by the Department of the Treasury. These checks were sent out beginning the week of July 23, 2001 and continued until the week of September 24, 2001. Those taxpayers who as of these dates had not filed their 2000 tax return did not receive the check until the IRS had processed the 2000 return. These payments were commonly referred to as tax rebates, although the IRS referred to them as advance payments of a 2001 tax credit.

The tax rebates were substantial, both from the point of view of the representative household or in aggregate. They amounted to $\$ 38$ billion, or approximately 0.4 percent of annual GDP. Median family income in 2000 was about $\$ 41,000$, so a $\$ 600$ rebate represents about 1.5 percent of median annual income and a greater share of disposable income for the typical household. Because the size of the rebate is capped, it declines as a fraction of income as income rises once a family receives the maximum rebate.

The rebates are a small part of the overall tax package, although the most significant part of the tax cuts implemented in 2001. The official revenue estimate 
produced by the Joint Committee on Taxation put the cost over 11 years at $\$ 1.349$ trillion. In terms of revenue impact, the largest component was a phased-in reduction in all of the marginal tax rates. By 2006, the top 39.6 percent bracket would be 35 percent, the 36 percent bracket would be 33 percent, the 31 percent bracket would be 28 percent, and the 28 percent bracket would be 25 percent. The new law also included such items as a phase-out of limitations on itemized deductions and restrictions on personal exemptions, an expansion of the child and dependent care tax credits, and an increase in the standard deduction for married couples. The estate and gift tax exemption levels were gradually increased and the rate structure gradually lowered, leading to a complete abolition of the estate tax in 2010. ${ }^{1}$ Clearly, high-income households and those with large estates had future taxes reduced by substantially more than the amount of the rebate.

The rebate corresponds to a new 10 percent income tax bracket for a portion of taxable income that was previously taxed at 15 percent, effective for taxable years beginning January 1,2001 . The 10 percent bracket applied to the first $\$ 6,000$ of taxable income for single individuals, $\$ 10,000$ of taxable income for heads of household, and $\$ 12,000$ for married couples filing joint returns. The tax rebate scheme was designed to deliver the benefit of the new 10 percent income tax rate in a highly visible way during calendar year 2001. Thus, the maximum rebate for a married couple filing jointly was 5 percent of $\$ 12,000$, or $\$ 600$. The rebates for taxpayers with other marital status were calculated in the same manner.

\footnotetext{
${ }^{1}$ Strikingly, both the income tax and the state tax were designed to sunset, i.e., return to pre-2001 law, after December 31, 2010.
} 
Although the rebate was an advance credit for a reduction in tax year 2001 tax liability, its amount was calculated on the basis of taxable income in tax year 2000. In the case of taxpayers who would have received a lower credit based on actual taxable income in 2001, the difference was forgiven, and no reconciliation was required. Those taxpayers who were entitled to receive a larger rebate on the basis of actual 2001 taxable income could claim it when they filed their 2001 tax year return in calendar year 2002.

Beginning in mid-July, the Treasury sent out notices to families informing of the amount of their rebate and providing documentation to be used in filing 2001 tax returns. The actual checks were mailed over 10 weeks, from the weeks of July 23 to September 24. Which week a taxpayer received the check depended on the second to last digit of the Social Security number. ${ }^{2}$ The Treasury calculated that 92 million taxpayers would get a rebate check, with 72 million receiving the full amount, and the rebate checks totaling \$38 billion.

\footnotetext{
${ }^{2}$ In addition, a one percentage point reduction in the $28,31,36$, and 39.6 percent brackets was effective on July 1,2001. Starting at that time, the standard amount of employer withholding was reduced for taxpayers at the (new) 27 percent bracket and above. (Tax liabilities were reduced effective January 1, 2001 by reducing the 28 percent rates and above by 0.5 percentage point.) For a married couple with two exemptions, this withholding bracket was reached at $\$ 55,700$ of annual payroll income. See Internal Revenue Service (2001). For income above that threshold, withholding was reduced by 1 percent of income beginning in July 1 . Annual household income of about $\$ 56,000$ is about at the 63rd percentile of the income distribution. See U.S. Bureau of the Census, Census 2000 Supplementary Survey Summary Table P069 (download from Census Bureau WWW site). Thus, for most households withholding was not changed. For all but the highest-income households, the decrease in withholding in 2001 was low relative to the rebate. For example, a married couple would have to have an annual payroll income of about $\$ 175,000$ in order for the change in withholding over the last six months of 2001 to be $\$ 600$, the usual size of the tax rebate check. Hence, the receipt of the rebates was confounded by a change in withholding, but this change was significant only for a few high-income households.
} 


\section{Survey Methodology}

In this paper, we study consumers' response to the income tax rebates of 2001 . We conducted a survey of a representative sample of households to measure whether or not they would spend the rebate. Our survey instrument was a rider on the University of Michigan Survey Research Center's Monthly Survey, also known as the Survey of Consumers. The survey's core content contains questions about expectations of economy-wide and family economic circumstances that are the basis of the Michigan Consumer Sentiment Index. The expectations components of the sentiment index can be used to test for liquidity constraints as an explanation of the pattern of spending. Additionally, we designed questions to shed light on specific economic or behavioral hypotheses that could explain the pattern of consumer response. Hence, the survey approach promises not only to quantify the response of spending to a change in income, but also to provide evidence on the underlying behavior that drives the spending response.

The Monthly Survey provides a representative sample of households in the contiguous 48 U.S. states and the District of Columbia. It is conducted by telephone throughout the month. The Monthly Survey begins with core questions used to construct the Consumer Sentiment Index. The core content is followed by several modules concerning spending and finances. The tax cut module immediately followed the core content. The Monthly Survey concludes with some questions about household demographics.

Our survey was conducted in August, September, and October 2001. The first two months of data were collected while households were in the midst of receiving rebate 
checks. By October, most households entitled to checks should have received them. The Monthly Survey provides both a representative sample of adult individuals and of households. We use the weights that enable us to construct a representative sample of households. These weights correct, among other things, for the over-sampling of households with more than one telephone line. They also exclude responses by adult children residing with their parents on the grounds that these respondents are uninformed about their families' finances. See Richard Curtin (no date).

The tax rebate survey module begins by briefly summarizing the policy and the rebate. The survey then asks whether the household will spend the rebate, save it, or use it to pay debt. Specifically, the key question was as follows:

Earlier this year a Federal law was passed cutting income tax rates and expanding certain credits and deductions. The tax cuts will be phased in over the next ten years. This year many households will receive a tax rebate check in the mail. In most cases, the tax rebate will be $\$ 300$ for single individuals and $\$ 600$ for married couples.

Thinking about your (family's) financial situation this year, will the tax rebate lead you mostly to increase spending, mostly to increase saving, or mostly to pay off debt?

Respondents are allowed to volunteer that they will not receive the rebate, although they are not prompted for that response. (This is question A31 of the survey. See the 
Appendix for the exact wording and order of the survey questions.) This question closely follows that used by Shapiro and Slemrod (1995) to study the 1992 change in withholding. ${ }^{3}$

The remainder of the survey module was designed to elicit responses that would be useful for testing various theories that explain spending behavior. These questions were designed within the limits of a telephone survey of the general public. There are limits - owing to survey costs, the attention span of respondents for a particular question, and the willingness of respondents to complete the whole survey—on the number of questions and the length of explanatory material. Moreover, it is necessary to map as best as possible economic concepts into everyday terms. Because the framing of questions may have an effect on responses, we attempted to design questions that would give unbiased responses.

The next question (A32) was designed to elicit (for those who said they would spend the rebate) whether it was for a particular purchase (a durable for example, but also a lumpy non-durable such as a trip) or for non-durables. This question illustrates issues that need to be confronted in crafting the survey. Terms such as "durable" or "lumpy" have technical meaning to economists, but are not necessarily meaningful to respondents. Of course, using non-technical terms in the survey leads to questions of interpretation

\footnotetext{
${ }^{3}$ The 1992 question was as follows: "The federal government has recently changed the amount of income tax that is being withheld from paychecks. On average, the change in withholding should increase your take-home pay by about $\$ 25$ per month, or by a total of about $\$ 250$ for all of 1992 . It also means that next year your tax refund will be about $\$ 250$ less than otherwise, or you will have to pay about \$250 more in taxes next year than otherwise. How do you think you will use the extra $\$ 25$ per month—do you think you will spend most of it, save most of it, use most of it to repay debts, or what?"
} 
when analyzing the responses. We settled on "particular item" and "day-to-day expenses" to describe these alternatives.

The next questions are relatively straightforward queries about the timing of the receipt of the rebate and timing of spending. (See A33, A34, and A36. A35 is an interviewer checkpoint.) Question A37 asks whether the household expects larger, similar, or smaller tax cuts in future years compared to the rebate. This information is critical for testing standard theories of consumption behavior. If future, credible, tax cuts are at least the size of the rebate, then the permanent income model of consumption would warrant an increase in consumption that could be at least the size of the rebate. Under the 2001 tax law, the median household will indeed get a tax cut in future years that is, in nominal dollars, exactly the size of the rebate. ${ }^{4}$ Many high-income households will get substantially larger tax cuts. This question also allows us to compare the respondents' prediction about their future tax cuts to an estimate of the cuts based on their economic and demographic circumstances. Behavior could differ from the permanent income model because respondents perceive the tax cuts to be short-lived.

The Barro/Ricardo hypothesis is that households will integrate the governments' budget constraint into their own decision-making, and therefore treat a tax cut as an increase in lifetime resources only if it is matched by a cut in government spending. Question A42 asks whether respondents think that the tax legislation as a whole will increase or decrease government spending. The responses to this question can be used to

\footnotetext{
${ }^{4}$ To get a larger tax cut, households will have to reach the income level of the old 28 percent bracket, which as noted above is reached at well above the median level of income. To get a smaller tax cut, the individual would have to have a decline in income and have a level of income lower than that of the new 10 percent bracket $(\$ 12,000$ of taxable income for a family). The tax cuts are scheduled to disappear in 2011.
} 
examine whether the Barro/Ricardo hypothesis accounts for the decision to spend the rebate. The next question (A43) asks whether the tax legislation would improve the family's personal financial situation over the next ten years. This question is designed to elicit the respondent's expectation about the permanent impact of the tax cut, potentially including the changes in government spending asked about in the previous question. ${ }^{5}$

The survey also includes questions to explore alternative theories of spending behavior. In particular, we were interested in testing for the importance of rule-of-thumb behavior in spending or saving the rebate. Designing questions that elicited meaningful information about such behavioral considerations proved a challenge. One cannot ask "Into what mental account did you deposit your rebate?" or "Did you add the rebate to your buffer stock? or "Do you have a spending or saving rule of thumb?" Our approach to elicit information about the procedures respondents used in forming their spending plans was first to ask whether the family had a budget (A38) and then to ask whether the budget had a spending target, a saving target, or a debt repayment target (A39). (Multiple answers were accepted, but not prompted for.) The specific aim of this question is to see if a budgetary rule of thumb could account for variations in consumer response to the rebate. One rule of thumb is to set expenditures and let blips in income add or subtract to cash balances or, more generally, savings. Another is to save a specific amount of periodic income (e.g., through a payroll savings plan) and spend the rest. The first rule of thumb leads to saving an infusion of income while the second leads to spending it. Neither involves high-frequency reoptimization of spending versus saving decisions.

\footnotetext{
${ }^{5}$ These questions, together with Question A41 that asks about the impact of the rebate on the economy, are grouped together at the end of the survey module. We grouped together the questions that bear on the overall impact of the policy.
} 
Either could be near-rational, depending on the process followed by shocks to income and consumption.

Finally, we asked how the respondent financed a hypothetical shock to consumption needs, specifically whether he or she would finance a major, unexpected car repair by using savings, by cutting back other expenses, or by borrowing (A40). Cutting back other spending could indicate liquidity constraints for individuals with little assets. For individuals with assets, cutting back spending might be interpreted as due to mental accounting or spending targets.

\section{Results}

\section{A. Tabular Analysis}

Of those that had already received or expected to receive the rebate, only 21.3 percent of survey respondents said they had or would mostly spend more because of the rebate check. When the responses are weighted as described in Section II, this figure rises slightly to 21.8 percent. All subsequent figures in the paper refer to weighted responses. (The counts of weighted responses in the tables are rounded to the nearest integer. The percentages are based on unrounded data.) Of those who would not spend, 59 percent said they would repay debt and 41 percent said they would devote the rebate to increased saving.

The 21.8 percent figure is far below the percentage that reported spending most of the increased after-tax income from the elder Bush's withholding change, and well below what most other research would suggest. It is in line, though, with what some other commercial surveys had suggested prior to the rebate program, although the wording of the question always differed. For example, in a Gallup Poll released on July 24, 2001, 17 
percent of those surveyed said they would spend the tax rebate, 32 percent said they would save or invest it, and 47 percent said they would use it to pay off bills.

Table 2 begins our investigation of what explains differences in spending propensities across households by displaying the responses by the level of income and the value of stocks owned. ${ }^{6}$ The spending fraction shows no trend within the bottom three income groups. It is higher for the top two income groups. Hence, the commonly expressed view that lower-income individuals have relative high propensity to spend (see Paul Krugman, New York Times, October 24, 2001) is not supported by our findings. Finally, not surprisingly, Table 2 reveals that low-income households were much more likely than higher-income households to expect not to receive the rebate.

The relationship of the consumer response to the tax rebate and stock ownership is strikingly non-monotonic. Among the slight majority of respondents that own no stock, 20.4 percent say they will spend it. Among those who do have a small amount of stock, the spending percentage is lower than for non-stockholders, but it is higher for those with more than $\$ 50,000$ of stock. This pattern can be rationalized as follows. Nonstockholders tend not to be savers, while stockholders are savers. (See Mankiw, 2000, for the spender/saver dichotomy.) Those stockholders with low wealth are trying to build wealth and therefore have a powerful saving motive; those with higher wealth may already have adequate assets, and therefore are spenders on the margin.

To the extent that income is a (negative) indicator of the presence of liquidity constraints, the results of Table 2 are counter-indicative. Those people who are more

\footnotetext{
${ }^{6}$ High stockholding is not a sufficient statistic for high wealth. Many high-wealth individuals do not hold stock. See Mankiw and Zeldes (1991). We focus on stock holdings simply because these are the only data on wealth in the survey.
} 
likely to be constrained (i.e., have lower income) are those that are more likely to mostly save, rather than mostly spend, the rebate. Table 3 A pursues this explanation by crosstabulating the spend-or-save responses with the answers to three questions designed to pick up the presence of liquidity constraints. We believe that a person is more likely to be liquidity constrained if he or she is financially worse off compared to the previous year, is financially worse off compared to what is expected for next year, or if they expect higher income next year. In none of these three cases is there a relationship between the answer to this question and the answer to the spend-or-save question that would indicate the importance of liquidity constraints. In fact, to the extent that any patterns emerge, they run in the reverse direction. People who are in worse financial condition than last year are less likely to spend more because of the rebate. The most surprising pattern of results applies to the question about this year's financial condition compared to what is expected next year. Here the relationship to spend-save plans is non-monotonic. The least likely to spend are those who expect to be worse off. That finding in and of itself is consistent with the liquidity constraint story. But the group second most likely to spend are those who expect to be better off next year, while the group most likely to spend are those who expect to be about as financially well off next year as this year. The liquidity constraint story suggests that the most likely to spend would be those who expect to be better off next year. The same pattern of results appears when the question asks about income next year rather than financial condition next year compared to this year.

Table 3B uses the joint distribution of retrospective and expected financial condition to provide a more powerful test of the liquidity constraint hypothesis. For example, if liquidity is a key determinant of spending behavior, households who are 
temporarily in bad financial condition (worse off than last year, but expecting to be better of next year) should have particularly high spending rates. In contrast, those who are in temporarily good financial condition (better off than last year, but expecting to be worse off next year) should have particularly low spending rates. Households in temporarily bad financial condition have a spending fraction of 16.0 percent, while those in temporarily good financial condition have a spending fraction of 22.0 percent. The liquidity constraint hypothesis predicts the opposite pattern. Under the liquidity constraint hypothesis, one would expect higher spending rates as one reads down the columns of Table 3B and lower rates as one reads across. These patterns are not apparent in the results.

In our previous survey-based study of the elder Bush's withholding change, we were also unable to relate spend-save intentions with any indicator of liquidity constraint, and we speculated that the explanation might be related to whether people used budget rules, or rules of thumb, to govern their behavior. Thaler (1990) argues that such rules of thumb, or mental accounts, are important for understanding specific decisions by consumers. Mankiw (2000) suggests that a behavioral dichotomy between spenders and savers is useful for understanding aggregate behavior and the effects of fiscal policy. Our questions about budgeting are an attempt to quantify such behavior.

The set of five questions detailed in Table 4 was designed to further investigate these hypotheses. About two-thirds of households report having a budget. Those who have budgets are slightly more likely to spend the rebate, though not statistically significantly so. Among households who have a budget, those who target spending are more likely to spend the rebate, those who target debt repayment are less likely to spend, 
and those who target saving are intermediate. (The survey allowed multiple targets to be mentioned, so the target categories are not mutually exclusive.) These findings are different that what one might have expected from an economic model of targeting, in which a household that spends a routine amount would save residual income and vice versa. The survey evidence is the opposite: target spenders tend to spend on the margin and target debt payers tend to save on the margin. There is no substantial difference in spending rates for target savers.

We included a question on the survey asking how a hypothetical unexpected, nonrecurring expense would be financed. The last group of results in Table 4 shows that those who would use saving to finance the expense are more likely to spend the rebate than those who would cut other spending or use credit. Those who would cut back spending for the unexpected expense might be liquidity constrained. If so, then one would have expected a high spending rate from the rebate for this group. Again, the liquidity hypothesis is rejected. Both those who would use saving or use credit for the unexpected expense are smoothing consumption, yet they spend the rebate at different rates.

Table 5 provides information about the relationship between spend-or-save plans and the respondents' outlook for the economy and fiscal policy. The first set of results relates the expected size of the tax cut to spending. Very few respondents expect to receive larger tax cuts, though those who do so do not have particularly high spending. As discussed in Section II, the tax rebate corresponds to the tax savings from the new 10 percent bracket, currently legislated to be in place for ten years. For most households, the only tax cut received from the 2001 legislation will be this rate cut. To get the benefit of 
the phased-in rate cuts on the higher brackets, taxable income will have to reach the level of the former 28 percent bracket. Hence, presuming the current legislation stays in place, the future benefit depends on expected future income. Since the higher tax brackets apply only to levels of income well above the median, most respondents should expect to receive future tax cuts no larger than their rebate under the 2001 tax law. Moreover, there is uncertainty about whether the currently legislated rate reductions will be the future law.

Table 6 takes a closer look at the expected size of the tax cut and its relationship to spending. It shows the fraction mostly spending the rebate by two objective indicators of the size of expected future tax cuts: current income level and expectations of future financial condition. (The expectation variable is for the next year. Though it does not capture fully the long-run outlook, it does control for whether current income is high or low relative to the future.) The first three rows of each cell show the fraction of respondents expecting a larger, same, or lower tax cut. We know from Table 5 that only a small fraction of respondents expects a larger tax in the future. Reading across columns of Table 6 shows that households that expect their financial condition to worsen generally expect smaller future tax cuts; the pattern is clearest for the middle three income groups. Reading down the panels shows that households that have higher income generally expect larger future tax cuts. Both these findings accord with current law. Yet, even of those households with high and rising income that are very likely to see higher tax cuts in the future, only a fairly low fraction — at most 0.31 — say they expect a larger tax cut. Hence, either they misperceive the current law or expect it to be changed. In either case, 
this pessimism about future tax cuts might explain the low spending propensity from the current rebate.

Returning to Table 5, the second panel shows that most households expect the tax legislation to have no effect on their overall personal finances over the next decade. The third panel shows that most households are equally pessimistic about the prospects for the tax cut improving short-run economic performance. There is also no statistically significant relationship between these expectations and the propensity to spend more because of the rebate.

The bottom panel of Table 5 investigates the role of expectations of future government spending. Under the Barro/Ricardo hypothesis, households should not spend their rebate unless the tax cut is accompanied by a cut in government spending. Only 19 percent of households expect that a cut in government spending will accompany the tax cuts. This expectation could help explain why, on average, the propensity to spend the tax rebate is low. Yet in the cross-section, there is little support for the Barro/Ricardo hypothesis because the spending propensity has no significant relationship with expectations of future government spending.

Table 7 shows some details about the spending plans of those who expected to spend the rebate. About 40 percent reported planning to spend the rebate on a particular item versus 60 percent for day-to-day expenses. Recall that we meant these categories to contrast durables or other lumpy items with nondurables. The next panel considers the 
timing of spending. More than three-quarters of the respondents expected to spend the rebate within a month and few planned to defer it to $2002 .^{7}$

\section{B. Timing of the Survey and Timing of Receipt of the Rebate}

The attacks on New York and Washington on September 11, 2001 occurred during the data collection period of the survey. The Michigan Consumer Sentiment Index had already fallen in the early part of September prior to the attack. It bounced up somewhat after the attack, although it ended the month at a much lower level than at the beginning of the month. Did the attack have an effect on spending the rebate? Table 8A appears to suggest that it did. For those who responded to the survey prior to September 11, 18.4 percent said they would spend the rebate. After September 11, the spending rate increased to 25.1 percent.

Interpreting the effect of singular events, even ones as significant as the attack, can be misleading. The change in the spending propensity following the attack might, by coincidence, arise from some other factor. The next panel in Table 8A shows such a confounding factor. There is a substantial and statistically significant impact of having already received the rebate on whether a respondent reports planning to spend it. There are a variety of reasons why a higher spending rate might be reported for those who have the rebate in hand. The rebate might be more salient if it is hand, though it is not clear why salience would favor spending over saving. Another possibility is that receiving the rebate confirms that the household is entitled to it and hence can add it to its lifetime resources available for spending. Having received the rebate has a large effect on

\footnotetext{
${ }^{7}$ The survey question refers to the lag in spending from the time of survey. The lag in spending from receipt of the rebate needs to be adjusted up or down depending on whether the rebate had been received at the time of the survey.
} 
spending, though it does not appear to matter whether the rebate was received very recently or not.

Table $8 \mathrm{~B}$ shows how timing of survey responses and timing of receipt of the rebate are confounded. During August, the first month of survey, relatively few households had received the rebate. By September, the majority had received it. By October, the overwhelming majority reported having received it.

To sort out these effects, we use a regression analysis. Table 9 reports the results of estimating a linear probability model for the propensity to spend the rebate. ${ }^{8}$ In column (A), the coefficient of the post-attack dummy is 6.7 percentage points and is statistically significant. Column (B) shows, however, that all the incremental spending comes from people interviewed in October. Distinguishing pre- and post-attack September in Column (C) does not change the conclusion that high spending is associated with being surveyed in October, which happens to be after the attack. Of course, by October, most respondents had received the rebate. Column (D) includes controls for having received the rebate. The estimated coefficients of having received the rebate are sizeable and jointly significant. Moreover, including the dummies for receipt of the rebate makes the October coefficient shrink and become insignificant. The September coefficient gets larger in absolute value, but remains insignificant. The postattack variable has a small and insignificant estimated coefficient.

\footnotetext{
${ }^{8}$ The dependent variable in these regressions equals one for those who reported mostly spending the rebate and zero for those who report saving or paying debt. An alternative would be to estimate a probit model. But recall that we argued above that the data should be weighted. Weighting induces heteroskedasticity and therefore renders the probit analysis inconsistent. Hence, we estimate linear probability models and use heteroskedastic standard errors for inference.
} 
Although the pattern of coefficients on the three receipt dummy variables might suggest a decay, the difference is not statistically significant $(\mathrm{p}=0.34)$. Moreover, although the month dummies have small t-statistics, they are marginally significant jointly ( $\mathrm{p}=0.10$ ). In Column (E) we thus present results including the month dummies and including a single dummy for having received the rebate regardless of timing of receipt. This is our preferred specification, and it strongly suggests that having already received the check increases the probability of responding that it would be mostly spent by nearly 8 percentage points. The last column shows the estimate of the effect on spending of having received the rebate leaving out the month controls - more than 9 percentage points. Given the marginal significance of the month dummies, this probably overstates the effect of receipt of the rebate.

About 60 percent of respondents reported receiving the rebate at the time of the survey. According to Column (E), receipt of the rebate adds 7.9 percentage points to the spending rate. Hence, one might add 3.2 percentage points $(.4 \times 7.9)$ to the spending rate to correct for the effect of ultimate receipt of the rebate on those who had not received it at the time of the survey. This would increase the estimated spending rate from 21.8 percent to 25.0 percent.

This analysis demonstrates the utility of the survey approach. The effect of receipt of the rebate is confounded with the effect of the attack. Our ability to control for receipt of the rebate among individuals responding to the survey after the attack allows us to avoid the incorrect inference that the attack changed spending. In contrast, a researcher with only aggregate time series might well have concluded that the effect of the attack was significant. 
The next section presents a more complete econometric analysis of the determinants of spending the rebate. In light of the results in Table 9, we include controls for the month of survey and the receipt of the rebate in these equations.

\section{Econometric Analysis}

The cross-tabulations suggest that the propensity for the rebate to increase spending is higher for those with higher incomes, is higher for those with more stock market wealth (although also relatively high for non-stockholders), but is not associated with indicators of liquidity constraints or how the tax cut legislation affected people's long-run financial position. It is correlated with budget rules, but not in a way that one would expect. In this section we further explore the determinants of the spend-or-save response with a set of regression analyses. In the analysis, we pool the save response with the repay debt response and contrast it with the spend response.

The main advantage of this approach is that we can investigate whether the simple correlations revealed in the cross-tabulations may be picking up, or masking, an association with a correlated variable. For example, Table 3 reveals that people who expect to be worse off next year are less likely to use the rebate as an opportunity to spend more. But, if those who expect to be worse off are generally low-income, then it may be the association with income, rather than with expected future financial condition, that is driving the relationship with the spend-or-save response. The regressions are estimated as linear probability models using the weighted data.

As a baseline, Table 10 presents the results of a regression analysis with only log income, dummies for levels of stockholding (no stock is the excluded category), for the respondent being married, for the presence of children in the household, and for levels of 
education of the respondent (less than high school is the omitted category). ${ }^{9}$ Tables 11 , 12 , and 13 focus additionally on each of the three sets of explanations of the spend-orsave response: personal financial condition, budgeting, and the outlook for the economy and policy.

The positive relationship with income found in Table 2 appears in Table 10 as well, although it remains statistically insignificant. Relative to non-stockholding, spending is U-shaped in stockholding, as is found in Table 2.

Being married raises the spending propensity and having children reduces it, although only with weak statistical significance. The age pattern of the spending propensity is uneven, with the 50 to 64 year old respondents having lower spending propensities than younger (but not the youngest) and especially older households. Education is not significantly related to spending. Since having children or the education levels have small and insignificant effects on spending, we drop them from subsequent regressions. Column (B) reports the baseline regression without these covariates.

Table 11 shows that the associations that run counter to the liquidity-constraints theory that appeared in Table 3 survive the regression framework. Being better off, either compared to the previous year or the one's expected condition next year, is positively associated with a propensity to spend. Column (A) of Table 11 shows that being better off or in the same financial condition this year relative to last year raises the propensity to spend by 7.1 and 6.5 percentage points, respectively, relative to those who are worse off than last year. Column (B) shows that expecting to be better off or in the same financial condition next year relative to this year raises the propensity to consume by 2.3 and 4.5

\footnotetext{
${ }^{9}$ See Appendix Table 1 for definition of these variables and their means.
} 
percentage points, respectively, relative to those who expect to be worse off next year than this year. Combining both the retrospective and expected financial conditions in Column (C) has only a small effect on the estimates compared to those in Columns (A) and (B). Hence, current financial conditions relative to the past and future conditions have a significant effect on spending, but not in the way one would expect if liquidity constraints explained behavior. In particular, those with transitorily bad financial condition have about the same spending propensity as those with transitorily good financial conditions. The highest spending propensities are associated with those that have a stable financial condition, retrospectively and going forward.

The regression reported in Column (D) of Table 11 confirms that one's expected financial condition has better predictive power for spending than expected income, as reported in the cross-tabulations of Table 3.

Table 12 shows that whether or not the respondent has a budget is not a significant determinant of spending the rebate [Column (A)], but conditional on having a budget, those whose budget targets spending have a higher propensity to spend relative to other budget rules [Column (B)]. Taken at its face value, this result means that households abandon their budget rule on the margin, i.e., those who have a spending target are more likely to spend the rebate.

Table 12, Column (C), provides further evidence that the cross-section differences in spending propensity are not well predicted by the standard model of consumption smoothing and liquidity constraints. A liquidity constraint would require households facing an unexpected expense to cut back other spending. For unconstrained households, using saving or using credit are both means of buffering consumption against shocks. 
Yet, Table 4 shows and the regression in Column (C) of Table 12 confirms that in the survey responses, only those who would use saving as a buffer against an unexpected expense are particularly likely to spend the rebate. The estimated coefficients of use credit and use saving are significantly different $(\mathrm{p}=0.01)$. Hence, there is a striking asymmetry between those who buffer shocks with credit and with savings.

Table 13 corroborates the impression gleaned from the cross-tabulations shown in Table 5 that neither budget rules nor beliefs about the impact of the tax cut legislation on one's own, or the country's, financial standing is montonically related to whether the consumer spends or saves the rebate. Paradoxically, although not statistically significantly, those who believe that the tax cuts would worsen or improve their own personal financial situation were more likely to mostly spend the rebate compared to those who think it would have no effect; the same pattern is true with respect to how the tax cuts affect the overall economic situation.

D. Response to a Temporary Tax Cut After the Attack The University of Michigan Survey Research Center fielded a new survey, How America Responds, in response to the attacks on New York and Washington, D.C. of September 11, 2001. The aim of the new survey was to study whether there were shifts in economic, social, political, and psychological attitudes following the attack. The survey included a version of the question about tax rebates analyzed above. It reads as follows:

This year many households have received a tax rebate check in the mail amounting to $\$ 300$ or $\$ 600$. Suppose the Federal government cut taxes an 
additional $\$ 1000$ per household for this year only and sent this $\$ 1000$ rebate to you (your family) in October of this year.

Thinking about your (family's) financial situation this year, will the tax rebate lead you mostly to increase spending, mostly to increase saving, or mostly to pay off debt?

Respondents were then given the same "Spend," "Save," or "Pay Debt" alternatives as in the main question under study in this paper. Hence, the question is identical except that the tax rebate is hypothetical, it is $\$ 1000$ instead of $\$ 300$ or $\$ 600$, and it is received only in one year.

The results are similar to this survey. Only fifteen percent of the respondents answered that they would mostly spend the rebate. The remainder was roughly equally split between saving and paying debt. The spending rate for the hypothetical tax cut, like that for the actual rebate, was not a function of the level of income. Given that the hypothetical rebate was temporary, a lower spending propensity can be rationalized by economic theory. Nonetheless, the spending percentage is close to what we find for the actual rebate. Like our estimate for the actual tax rebate, the spending propensity from the hypothetical rebate is much smaller than found in earlier studies.

\section{Literature on Propensity to Consume}

The standard methodological approach to this question has been to examine aggregate consumption data for signs of a break in behavior around the implementation date of a tax policy change. This approach has been applied to the most similar recent policy, the 
tax rebate of 1975. The Tax Reduction Act of 1975 provided for a 10 percent rebate of 1974 taxes up to a maximum of $\$ 200$, and totaled $\$ 8.1$ billion sent out from late April to mid-June of 1975. The 1975 tax bill also included a smaller, transitory income tax reduction that was subsequently made permanent, and a one-time Social Security bonus for retirees with no income taxes to rebate. Blinder (1981) finds that each rebate dollar raised consumption by about 16 cents in the quarter it was received, and still had substantial effects five to eight quarters afterwards. Hence, the cumulative effect is substantially larger than the impact effect and substantially larger than we find. Modigliani and Steindel (1977) find much smaller effects, however, and Blinder and Deaton (1985) were unable to precisely estimate the response. Poterba (1988), using monthly rather than quarterly consumption data, finds that consumption of nondurables increased by between 18 and 24 percent of the rebate in the month received, but found that the change in service consumption was negligible. Hence, despite the fact that the 1975 rebate was meant to be a temporary tax reduction, the time-series evidence suggest propensities to consume at least as great as we find, and substantially greater in the case of Blinder's study.

These aggregative studies focus on specific tax rebates as shocks to income. The literature on the excess sensitivity of consumption to predictable changes in income examines how consumption responds on average to predetermined movements in income. ${ }^{10}$ According to the permanent income model of consumption, consumption should adjust only when income moves unexpectedly. These studies find, however, that

${ }^{10}$ This line of research was begun by Flavin's (1981) extension of Hall's (1978) seminal work. Though there are some econometric difficulties with Flavin's approach [see 
consumption responds to predictable changes in income. The estimated aggregate propensity to consume from expected changes in income is between 40 and 50 percent. Similarly, there is a large literature on examining the excess reaction of consumption to income in data on households. ${ }^{11}$ A series of recent studies have used data on individuals to examine how the receipt of payments affects spending. The common thread of these studies is that consumption responds to changes in the timing of payments not associated with changes in lifetime resources. ${ }^{12}$ Parker (1999) examines whether spending changes when take-home pay increases in months after wage earners hit the earnings ceiling for Social Security payroll taxes. He finds that there is a correlation between take-home pay and consumption, although the evidence points to myopia or rule-of-thumb behavior rather than liquidity constraints as the source of the consumption/income correlation. Souleles (1999) studies spending from tax refunds. He concludes that almost two-thirds of every dollar of refund is spent within the quarter. Moreover, households that likely face liquidity constraints (those that are younger, have high debts, few liquid assets, and low income) quickly increase their spending on nondurables, while wealthier households quickly spend it on durable goods and may use part of the refund check later on summer vacations. Stephens (2001) studies whether the receipt of Social Security checks affects the timing of spending within the month. He finds a significant burst in spending in the week following receipt of the check. Since the regularity of these payments provides ample opportunity for households to make

Mankiw and Shapiro (1985)], the finding of excess sensitivity has been confirmed by a large literature. See Campbell and Mankiw (1989) and its successors.

${ }^{11}$ Hall and Mishkin (1982), Shapiro (1984), and Zeldes (1989) are early contributions. See Browning and Lusardi (1996) for a survey of this literature.

${ }^{12}$ Wilcox $(1989,1990)$ pioneered such studies in an aggregate time series settings. 
adjustments to avoid the correlation of spending with the receipt of the check, Stephens's finding suggests that some behavior other than liquidity constraints explains spending patterns.

Not all evidence from individual households suggest excess consumption from predictable changes in income. Hsieh (2001) finds that there is no evidence against consumption smoothing from changes in income from the large and predictable payments received by Alaskans from oil royalties. Similarly, Souleles (2000) finds that large and predictable tuition payments have little impact on parents' non-tuition expenditures.

The most methodologically similar paper is Shapiro and Slemrod (1995), which used survey responses to estimate the consumption response to a policy of George W. Bush's father. President George H. Bush in 1992 issued an executive order that changed the income tax withholding rates to increase after-tax income by about $\$ 29$ per month per worker, or an aggregate increase of $\$ 25$ billion in after-tax income. This study concluded that 43 percent of consumers spent the extra cash flow from the withholding change. This figure is similar to Campbell and Mankiw's (1989) estimate, based on aggregate time-series that 50 percent of income goes to "rule of thumb" consumers. Consistent with the 2001 evidence, the study revealed no relationship between the response to the withholding change and indicators of liquidity constraint based on one's income and financial condition in the current year compared to the previous year and expectations about the next year. Shapiro and Slemrod speculated that the results might be consistent with consumers following some sort of rule of thumb, or near-rational, behavior. The evidence that this paper presents on budget targeting does suggest that budget rules 
matter, although if "target spending" means that saving is the residual in a rule of thumb, this evidence does not support the simplest behavioral model.

Although the 1992 and current surveys are similar in wording and design, the policy changes were different. We have already emphasized that the 1992 policy change affected only the timing of tax payments while the 2001 change, if taken at face value, had a substantial effect on their present value. The 2001 changes also might have been more salient. They were more heavily discussed in the press and also came in the form of a single check rather than a series of 10 monthly increments to take-home pay. It is not obvious, however, that increased salience would generate a higher rate of saving.

\section{Conclusions}

Only 22 percent of households report that they had spent or expected to mostly spend the income tax rebate of 2001. This spending rate perhaps needs to be corrected upwards by as much as 3 percentage points to account for the effect on survey responses of the timing of receipt of the rebate. Given that the tax legislation in place at the time of the survey provided for ten years of tax cuts of at least the amount of the rebate for most households receiving the rebate, the tax rebate apparently corresponds to a substantial increment to lifetime resources. Hence, standard economic theory would suggest a spending rate close to one. It is therefore very surprising to find a spending propensity much closer to zero, a surprise that is compounded by the likelihood that some households are liquidity constrained, which raises the propensity to consume even out of a temporary tax cut.

The very low propensity to consume is even more surprising in the context of previous estimates. There is substantial evidence- - both from aggregate time series and from data on households - that the propensity to consume out of changes in income is 
substantial. Indeed, the propensity to spend in situations where an unconstrained, forward-looking consumer would smooth consumption is generally found to be substantially larger than what we find.

Economists are, of course, skeptical of survey responses. We are supposed to be interested in what people do, not what they say they will do or have done. We have argued elsewhere [Shapiro and Slemrod (1995)] that this view of the survey evidence is too limited. In any case, it is very difficult to use time-series or cross-section evidence on actual behavior to study events such as the tax rebate. It is a single event that affects most households by the same amount. In the time series, any other aggregate event could account for changes in spending associated with the timing of the rebate. In the cross section, most households will face the same shock.

There are also legitimate concerns that the wording of the survey may affect the results in ways that are difficult to predict. That our survey question has been tested in the field provides an important defense against these concerns. In 1992, survey respondents reported a much higher spending rate for a temporary tax withholding change based on a nearly identical survey instrument. These findings are in line with other evidence on the propensity to consume. That survey respondents reported low propensities to consume from the 2001 rebate hence cannot therefore be attributed to the survey methodology.

What accounts for the very low propensity to consume from the 2001 tax rebate? The cross-sectional analysis of Section III provides some clues. Respondents are quite pessimistic about the size of future tax rebates. Even among respondents with high and increasing income who should benefit substantially from the legislated reduction in 
marginal tax rates, no more than a $1 / 3$ expect to receive future tax cuts from the 2001 legislation greater than the size of the rebate. Many households who received the rebate expect to benefit in the future by less than the size of the rebate.

Wealth holding is one of the most powerful predictors of spending propensity in the cross-section. Those with some stockholdings, but low levels of stock-market wealth, are particularly likely to save the rebate. This is consistent with a spender/saver model. Those without stock portfolios may be spenders. Those with stock portfolios, but with a low value of stock, may be in saving mode as they try to build assets. Those with high asset values may already have adequate accumulated saving. Moreover, they tend to be high-income households for whom the size of the rebate is relatively small.

The cross-section results also fail to support some possible theories of the low propensity to spend. In particular, because we find that propensity to spend the tax cut is not associated with expectations of lower government spending, the cross-section results do not support the Barro/Ricardo integration of the household and government budget constraints.

There are, of course, limitations to the cross-sectional results. First, because the vast majority of households do not spend the rebate, there is little cross-section variation in behavior to explain. It is not thus surprising that the R-squared statistics reported in Tables 11, 12, and 13 are fairly low. Second, and more fundamentally, if there is an aggregate change in behavior such that spending propensities have shifted downward, cross-section techniques will be of limited use in pinpointing it. The survey does indicate that there is a high degree of aggregate pessimism about the size of future tax cuts and the possibility that government spending will be restrained. These findings can explain a low 
spending propensity on average even if there is not sufficient variation in these beliefs to predict which of the few households will actually spend their rebate.

Regardless of the reasons for the low rate of spending, the findings of this paper have significant implications for the impact of fiscal policy on the economy. First, the low propensity to consume implies that the 2001 tax rebate will have a very small impact on aggregate demand. The rebate was added to the 2001 tax bill explicitly to provide a short-run stimulus. This research suggests that policymakers will be disappointed. Moreover, the new survey conducted after the terrorist attack suggests that further temporary tax cuts will be relatively ineffective in stimulating spending.

Second, to the modest extent that spending from the rebate was spent, low-income households are not less likely to spend. This finding runs counter to the belief that a tax rebate would be more effective at stimulating aggregate demand were it targeted at lowincome households. It is, though, conceivable that the propensity to consume would be higher among those households whose income was too low to qualify for the first round of rebates. This survey does not rule that possibility out.

Third, our finding of a very low propensity to consume raises a cautionary note about the effectiveness of fiscal policy in general. Consumer behavior appears to have shifted from what most economists would have expected, both based on economic theory and earlier evidence. It is possible that key parameters such as the propensity to consume are contingent on aggregate conditions in ways that are difficult to anticipate or model. One can speculate about why the spending propensity might have shifted downward under the circumstances of mid-year 2001. Perhaps the negative wealth shocks of the previous two years placed consumers in an asset-rebuilding mode. There may be costs to 
cutting back consumption, such as a force of habit. Such preferences may cause households to allocate the rebate to saving even if they are saving a very low fraction of current income. Future research may clarify the causes of the large apparent decline in the marginal propensity to consume. In the meantime, these findings illustrate the peril of extrapolating the impact of current policies from past behavior. 


\section{REFERENCES}

Browning, Martin and Lusardi, Annamaria. "Household Saving: Micro Theories and Micro Facts.” Journal of Economic Literature 34 (December 1996) 1797-1855.

Blinder, Alan S. “Temporary Income Taxes and Consumer Spending.” Journal of Political Economy 89 (1981) 26-53.

Blinder, Alan S. and Deaton, Angus. "The Time Series Consumption Function Revisited.” Brookings Papers on Economic Activity (1985:2) 465-511.

Campbell, John Y. and Mankiw, N. Gregory. "Consumption, Income, and Interest Rates: Reinterpreting the Time Series Evidence," in Olivier Jean Blanchard and Stanley Fischer, eds., NBER Macroeconomics Annual. Cambridge, MA: MIT Press, 1989, pp. 185-216.

Curtin, Richard T. "Survey of Consumers." Survey Research Center, University of Michigan, no date.

Hall, Robert E. "Stochastic Implications of the Life Cycle-Permanent Income Hypothesis: Theory and Evidence." Journal of Political Economy 86 (Dec. 1978) 97187.

Hall, Robert E. and Mishkin, Frederic S. "The Sensitivity of Consumption to Transitory Income: Estimates From Panel Data on Households." Econometrica 50 (Mar. 1982) $461-81$.

Hsieh, Chang-Tai. "Do Consumers Respond to Anticipated Income Changes? Evidence From the Alaska Permanent Fund." Unpublished paper, Princeton University (September 2001).

Flavin, Marjorie A. "The Adjustment of Consumption to Changing Expectations About Future Income.” Journal of Political Economy 89 (Oct. 1981) 974-1009.

Mankiw, N. Gregory. "The Spenders-Savers Theory of Fiscal Policy." American Economic Review Papers and Proceedings 90 (May 2000) 120-5.

Mankiw, N. Gregory and Shapiro, Matthew D. "Trends, Random Walks, and Tests of the Permanent Income Hypothesis." Journal of Monetary Economics 16 (September 1985) 165-174.

Mankiw, N. Gregory and Zeldes, Stephen P. "The Consumption of Stockholders and Nonstockholders." Journal of Financial Economics 29 (1991) 97-112.

Modigliani, Franco and Steindel, Charles. "Is a Tax Rebate an Effective Tool for Stabilization Policy?" Brookings Papers on Economic Activity (1977) 175-209. 
Parker, Jonathan. "The Reaction of Household Consumption to Predictable Changes in Social Security Taxes.” American Economic Review 89 (1989) 959-73.

Poterba, James M. “Are Consumers Forward Looking? Evidence from Fiscal Experiments?” American Economic Review 78 (1988) 413-8.

Shapiro, Matthew D. "The Permanent Income Hypothesis and the Real Interest Rate: Some Evidence from Panel Data.” Economics Letters 14 (1984) 93-100.

Shapiro, Matthew D. and Slemrod, Joel. "Consumer Response to the Timing of Income: Evidence from the a Change in Tax Withholding." American Economic Review 85 (1995) 274-83.

Souleles, Nicholas N. "College Tuition and Household Savings and Consumption." Journal of Public Economics 77 (August 2000) 185-207.

Souleles, Nicholas N. "The Response of Household Consumption to Income Tax Refunds." American Economic Review 89 (1999) 947-58.

Stephens, Melvin, Jr.“'3rd of tha Month': Do Social Security Recipients Smooth Consumption Between Checks?" Unpublished paper, Carnegie-Mellon University (June 2001).

Thaler, Richard H. “Anomalies: Saving, Fungibility, and Mental Accounts.” Journal of Economic Perspectives 4 (1990) 193-205.

Wilcox, David W. "Social Security Benefits, Consumption Expenditures, and the Life Cycle Hypothesis.” Journal of Political Economy 97 (Apr. 1989) 288-304.

Wilcox, David W. "Income Tax Refunds and the Timing of Consumption Expenditure." Economic Activity Section Working Paper No. 106, Board of Governors of the Federal Reserve System. Washington, DC, April 1990.

Zeldes, Stephen P. “Consumption and Liquidity Constraints: An Empirical Investigation.” Journal of Political Economy 97 (Apr. 1989) 305-46.

Internal Revenue Service. "New Withholding Tables for 2001" Publication 15-T. (June 2001). 


\section{Appendix: Survey Instrument}

A31. Earlier this year a Federal law was passed cutting income tax rates and expanding certain credits and deductions. The tax cuts will be phased in over the next ten years. This year many households will receive a tax rebate check in the mail. In most cases, the tax rebate will be $\$ 300$ for single individuals and $\$ 600$ for married couples.

Thinking about your (family's) financial situation this year, will the tax rebate lead you mostly to increase spending, mostly to increase saving, or mostly to pay off debt?

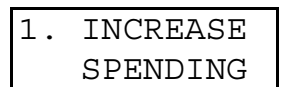
SPENDING

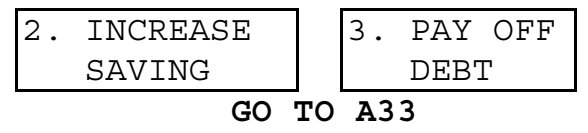
6. (IF VOLUNTEER) WILL NOT GET REBATE GO TO A38

\begin{tabular}{|ll|}
\hline 8. $\begin{array}{l}\mathrm{DON}^{\prime} \mathrm{T} \\
\mathrm{KNOW}\end{array}$ \\
\hline GO TO A33
\end{tabular}

A32. Will the increase in spending be for a particular item that you otherwise would not have purchased, or will it be spent mostly on dayto-day expenses?

1. PARTICULAR ITEM 2. DAY-TO-DAY EXPENSES

8. DON'T KNOW

A33. (Have you/Has your family) already received your tax rebate?
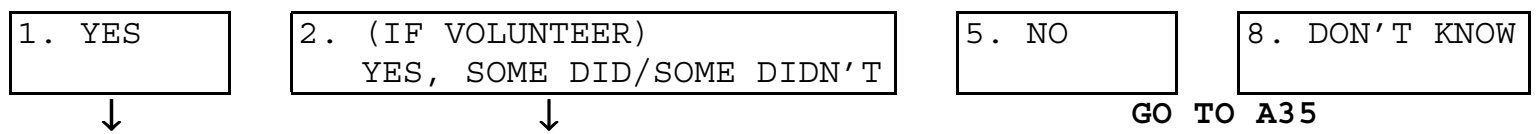

A34. Was the tax rebate check received within the last week, more than a week ago but within the last four weeks, or more than four weeks ago?

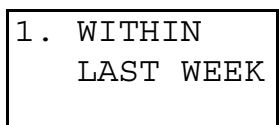

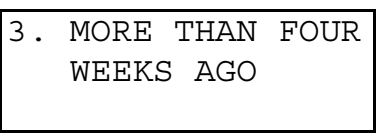
8. $\mathrm{DON}^{\prime} \mathrm{T}$ KNOW


1. WILL SPEND REBATE $(\mathrm{A} 31=1)-->$ GO TO A36

2. ALL OTHERS --> GO TO A37

A36. When do you plan on spending most of your tax rebate--have you already spent most of it, will you spend most of it within a month, will you spend most of it within two months, will you spend most of it before the end of the year, or will you not spend most of it until next year?

\begin{tabular}{|c|c|c|c|c|c|}
\hline $\begin{array}{ll}\text { 1. } & \text { ALREADY } \\
& \text { SPENT }\end{array}$ & \begin{tabular}{|ll}
2. & WITHIN \\
& MONTH
\end{tabular} & \begin{tabular}{|ll}
3. & WITHIN \\
& 2 MONTHS
\end{tabular} & 4. BY END & 5. NEXT & \begin{tabular}{|ll} 
8. & $\mathrm{DON}^{\prime} \mathrm{T}$ \\
& $\mathrm{KNOW}$
\end{tabular} \\
\hline
\end{tabular}

A37. Now thinking about the tax cuts you (and your family) expect in future years, do you think that your (family's) annual tax cut will be larger than this year's tax rebate, about the same size, or smaller than this year's tax rebate?

1. LARGER THAN REBATE

\begin{tabular}{rr|}
\hline 3. & SAME \\
SIZE
\end{tabular}

8. $\mathrm{DON}^{\prime} \mathrm{T}$ KNOW

A38. Do you have a (family) budget, or otherwise plan, your spending and saving?

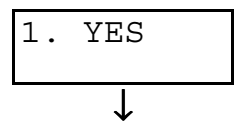

$$
\begin{array}{|l|}
\hline \text { S. NO } \\
\hline \text { GO TO A40 }
\end{array}
$$

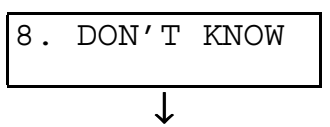

A39. People budget in different ways. Do you (and your family) generally try to keep your spending within a certain limit or do you focus more on trying to save regular amounts of money, or to pay off regular amounts of debt?

(CHECK ALL THAT APPLY -- DO NOT PROBE FOR ADDITIONAL MENTIONS)
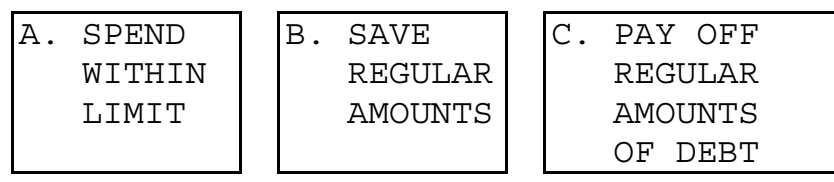
D. (IF VOLUNTEERED) DOESN'T BUDGET/ BUDGETS IN DIFFERENT WAY


A40. If (you/your family) had an unexpected expense, such as a one-time car repair, would you pay for it mostly by taking the money out of savings, mostly by cutting back on other spending, or mostly by using credit or borrowing?

\begin{tabular}{|l|}
\hline USE \\
SAVINGS \\
\hline
\end{tabular}

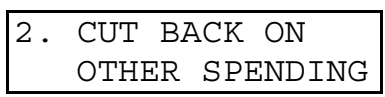

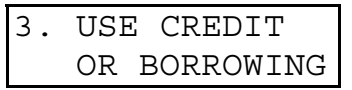

A41. Do you think the tax rebates will improve conditions in the national economy during the year ahead, will the tax rebates worsen conditions in the national economy during the year ahead, or will the tax rebates not have much impact on the national economy during the year ahead?

\begin{tabular}{ll|}
\hline 1. & IMPROVE \\
& ECONOMY
\end{tabular}

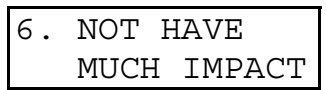

\begin{tabular}{rl|} 
8. & $\begin{array}{l}\mathrm{DON}^{\prime} \mathrm{T} \\
\mathrm{KNOW}\end{array}$ \\
\hline
\end{tabular}

A42. Now thinking about the federal tax cut legislation as a whole, not just this year's rebate, do you think the tax cuts will lead to increased future government spending, decreased future government spending, or will future government spending not change much as a result of the federal tax cut?

1. INCREASED SPENDING

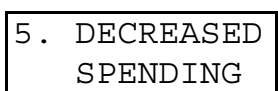
SPENDING
6. SPENDING NOT CHANGE

8. $\mathrm{DON}^{\prime} \mathrm{T}$ KNOW

A43. Thinking of your (family's) financial situation over the next ten years, do you think the tax cut legislation will make you better off financially, make you worse off financially, or will it not make much difference to your financial situation?

1. BETTER OFF FINANCIALLY

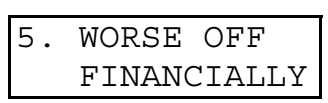

8. $\mathrm{DON}^{\prime} \mathrm{T}$ KNOW 
Table 1-Plans To Spend or Save Rebate?

\begin{tabular}{|c|c|c|c|c|c|c|c|}
\hline & $(\mathrm{A})$ & (B) & (C) & (D) & $(E)$ & $(F)$ & $(\mathrm{G})$ \\
\hline & $\begin{array}{c}\text { Total } \\
\text { Responses }\end{array}$ & $\begin{array}{l}\text { Spend } \\
\text { Rebate }\end{array}$ & $\begin{array}{c}\text { Save } \\
\text { Rebate }\end{array}$ & $\begin{array}{c}\text { Pay Debt } \\
\text { With Rebate }\end{array}$ & $\begin{array}{c}\text { Will Not } \\
\text { Get Rebate }\end{array}$ & $\begin{array}{c}\text { Don't Know/ } \\
\text { Refused }\end{array}$ & $\begin{array}{c}\text { Spend } \\
\text { Percentage }\end{array}$ \\
\hline Unweighted & 1506 & 267 & 423 & 563 & 204 & 49 & $21.3 \%$ \\
\hline Weighted & 1444 & 256 & 376 & 544 & 223 & 45 & $21.8 \%$ \\
\hline
\end{tabular}

Note: The first row gives unweighted responses. The second row gives weighted responses (rounded to nearest whole number). Columns $A$ through $F$ give number of responses. Column $G$ gives the number in column $B$ divided by the sum of the numbers in column $B$ through $D$.

Percentages based on unrounded responses. 
Table 2-Spend or Save Rebate? Responses by Income and Wealth

\begin{tabular}{|c|c|c|c|c|c|c|c|}
\hline & $(\mathrm{A})$ & (B) & (C) & (D) & $(\mathrm{E})$ & $(F)$ & (G) \\
\hline Income and wealth & Frequency & $\begin{array}{l}\text { Spend } \\
\text { Rebate }\end{array}$ & $\begin{array}{l}\text { Save } \\
\text { Rebate }\end{array}$ & $\begin{array}{c}\text { Pay Debt } \\
\text { With Rebate }\end{array}$ & $\begin{array}{l}\text { Will Not } \\
\text { Get Rebate }\end{array}$ & $\begin{array}{c}\text { Spend } \\
\text { Percentage }\end{array}$ & $p$-value \\
\hline \multicolumn{8}{|l|}{ Income } \\
\hline 0 to 20,000 & $20.4 \%$ & 23 & 27 & 81 & 132 & $17.6 \%$ & \multirow{5}{*}{0.076} \\
\hline 20,001 to 35,000 & $20.1 \%$ & 42 & 74 & 109 & 35 & $18.8 \%$ & \\
\hline 35,001 to 50,000 & $17.9 \%$ & 40 & 74 & 103 & 14 & $18.6 \%$ & \\
\hline 50,001 to 75,000 & $18.8 \%$ & 63 & 66 & 105 & 10 & $27.0 \%$ & \\
\hline More than 75,000 & $22.9 \%$ & 69 & 95 & 123 & 9 & $24.1 \%$ & \\
\hline \multicolumn{8}{|l|}{ Stock } \\
\hline No stock & $51.1 \%$ & 109 & 150 & 275 & 182 & $20.4 \%$ & \multirow{6}{*}{0.004} \\
\hline 1 to 15,000 & $9.3 \%$ & 15 & 33 & 70 & 11 & $12.8 \%$ & \\
\hline 15,001 to 50,000 & $11.0 \%$ & 25 & 43 & 73 & 11 & $18.0 \%$ & \\
\hline 50,001 to 100,000 & $8.6 \%$ & 28 & 36 & 48 & 8 & $24.9 \%$ & \\
\hline 100,000 to 250,000 & $12.1 \%$ & 49 & 65 & 50 & 6 & $29.8 \%$ & \\
\hline More than 250,000 & $7.8 \%$ & 30 & 48 & 27 & 4 & $28.4 \%$ & \\
\hline
\end{tabular}

Note: Tabulations based on weighted responses with "don't know" and "refused" excluded. Column A gives the frequency of response by rows. Columns $B$ through $E$ give number of weighted responses (rounded to nearest whole number). Column $F$ gives the number of responses in Column B divided by the sum of responses in Columns B, C, and D. Column $G$ gives the $p$-value for the hypothesis that the spend percentages in Column $\mathrm{F}$ are equal. Percentages and p-values based on unrounded responses. 
Table 3-Plans to Spend or Save Rebate

A. Responses by Financial Condition

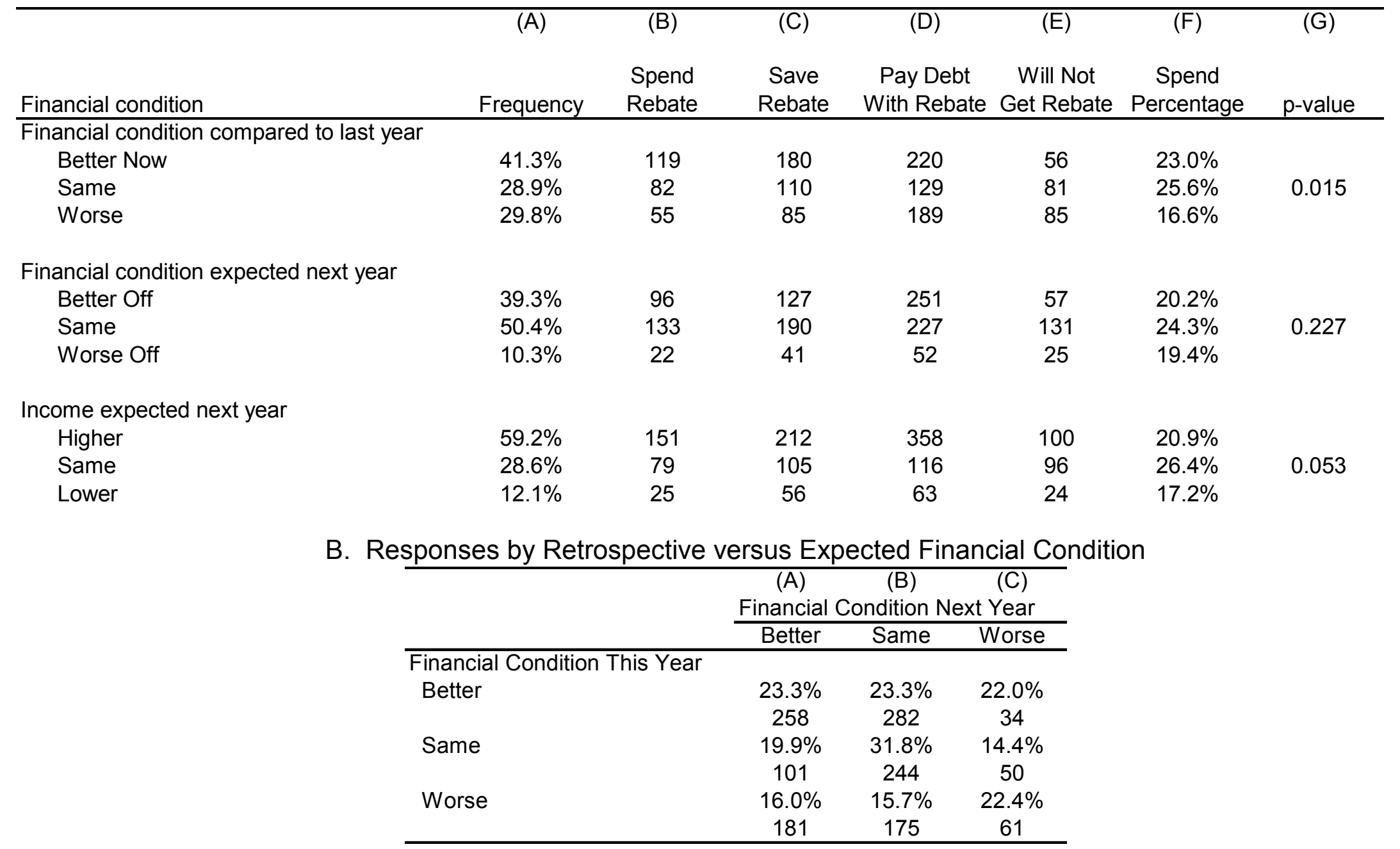

Note: Rows are condition this year compared to last year. Columns are condition expected next year compared to this year. First number is cells are percentage of respondents spending the rebate. The second number is the frequency. See also note to Table 2. 
Table 4-Spend or Save Rebate: Responses by Budgeting

\begin{tabular}{|c|c|c|c|c|c|c|c|}
\hline & $(\mathrm{A})$ & (B) & $(\mathrm{C})$ & (D) & $(\mathrm{E})$ & $(\mathrm{F})$ & $(\mathrm{G})$ \\
\hline Family budgeting & Frequency & $\begin{array}{l}\text { Spend } \\
\text { Rebate }\end{array}$ & $\begin{array}{c}\text { Save } \\
\text { Rebate }\end{array}$ & $\begin{array}{c}\text { Pay Debt } \\
\text { With Rebate }\end{array}$ & $\begin{array}{c}\text { Will Not } \\
\text { Get Rebate }\end{array}$ & $\begin{array}{c}\text { Spend } \\
\text { Percentage }\end{array}$ & $p$-value \\
\hline Yes & $65.6 \%$ & 175 & 236 & 373 & 129 & $22.3 \%$ & 0.555 \\
\hline No & $34.4 \%$ & 81 & 139 & 168 & 91 & $20.8 \%$ & \\
\hline \multicolumn{8}{|l|}{ If budget, Target spending } \\
\hline Yes & $50.8 \%$ & 95 & 123 & 166 & 75 & $24.7 \%$ & 0.077 \\
\hline No & $49.2 \%$ & 76 & 109 & 207 & 53 & $19.5 \%$ & \\
\hline \multicolumn{8}{|l|}{ If budget, Target saving } \\
\hline Yes & $39.0 \%$ & 75 & 123 & 121 & 33 & $23.5 \%$ & 0.426 \\
\hline No & $61.0 \%$ & 96 & 109 & 251 & 95 & $21.1 \%$ & \\
\hline \multicolumn{8}{|c|}{ If budget, Target debt repayment } \\
\hline No & $56.4 \%$ & 107 & 162 & 164 & 77 & $24.8 \%$ & \\
\hline \multicolumn{8}{|c|}{ If budget, Target saving or debt repayment } \\
\hline Yes & $68.2 \%$ & 111 & 155 & 273 & 77 & $20.6 \%$ & 0.128 \\
\hline No & $31.8 \%$ & 60 & 77 & 100 & 50 & $25.5 \%$ & \\
\hline \multicolumn{8}{|c|}{ How to pay for unexpected expense } \\
\hline Use Savings & $50.7 \%$ & 158 & 243 & 209 & 82 & $25.9 \%$ & \\
\hline Cut Back Spending & $27.0 \%$ & 52 & 79 & 167 & 71 & $17.4 \%$ & 0.001 \\
\hline Use Credit & $22.4 \%$ & 39 & 49 & 159 & 59 & $15.7 \%$ & \\
\hline
\end{tabular}

Note: See note to Table 2. Multiple mentions are allowed for the budget targets, so the responses are not mutually exclusive. The budget target question also allowed, though did not prompt for, budgeting other ways. Seven respondents (weighted) gave this reply. 
Table 5-Spend or Save Rebate? Response by Outlook for Economy and Policy

\begin{tabular}{|c|c|c|c|c|c|c|c|}
\hline & $(\mathrm{A})$ & (B) & (C) & (D) & $(\mathrm{E})$ & $(F)$ & (G) \\
\hline Economic and policy outlook & Frequency & $\begin{array}{l}\text { Spend } \\
\text { Rebate }\end{array}$ & $\begin{array}{l}\text { Save } \\
\text { Rebate }\end{array}$ & $\begin{array}{l}\text { Pay Debt } \\
\text { With Rebate }\end{array}$ & $\begin{array}{l}\text { Will Not } \\
\text { Get Rebate }\end{array}$ & $\begin{array}{l}\text { Spend } \\
\text { Percentage }\end{array}$ & $\mathrm{p}$-value \\
\hline \multicolumn{8}{|l|}{ Size of future tax cuts } \\
\hline Larger & $16.1 \%$ & 40 & 43 & 92 & NA & $22.9 \%$ & \multirow{3}{*}{0.703} \\
\hline Same Size & $47.1 \%$ & 103 & 167 & 241 & NA & $20.1 \%$ & \\
\hline Smaller & $36.8 \%$ & 86 & 131 & 182 & NA & $21.6 \%$ & \\
\hline \multicolumn{8}{|c|}{$\begin{array}{l}\text { Impact of tax cuts on personal finances } \\
\text { over next } 10 \text { years }\end{array}$} \\
\hline Better Off & $23.1 \%$ & 78 & 94 & 122 & 22 & $26.5 \%$ & \multirow{3}{*}{0.022} \\
\hline No Change & $72.0 \%$ & 156 & 261 & 385 & 182 & $19.5 \%$ & \\
\hline Worse Off & $5.0 \%$ & 16 & 13 & 29 & 11 & $27.8 \%$ & \\
\hline \multicolumn{8}{|c|}{ Impact of tax cut on economy next year } \\
\hline Improve Economy & $27.2 \%$ & 86 & 110 & 127 & 45 & $26.7 \%$ & \multirow{3}{*}{0.003} \\
\hline Not Much Impact & $62.9 \%$ & 132 & 228 & 357 & 134 & $18.5 \%$ & \\
\hline Worsen Economy & $9.9 \%$ & 30 & 26 & 54 & 23 & $27.5 \%$ & \\
\hline \multicolumn{8}{|c|}{ Impact of tax cut on government spending } \\
\hline Increased Spending & $26.1 \%$ & 68 & 89 & 137 & 49 & $23.0 \%$ & \multirow{3}{*}{0.700} \\
\hline Spending Not Change & $54.7 \%$ & 126 & 185 & 294 & 114 & $20.9 \%$ & \\
\hline Decreased Spending & $19.3 \%$ & 51 & 82 & 90 & 30 & $22.9 \%$ & \\
\hline
\end{tabular}

Note: See note to Table 2. 


\section{Table 6-Expected Future Tax Cut and Spending of Rebate: By Income Group and Expected Future Income}

\begin{tabular}{|c|c|c|c|c|}
\hline \multirow{3}{*}{ Income } & & \multirow{2}{*}{\multicolumn{3}{|c|}{$\begin{array}{ccc}(\mathrm{A}) & (\mathrm{B}) & (\mathrm{C}) \\
\text { Financial Condition Next Year }\end{array}$}} \\
\hline & & & & \\
\hline & & Better Off & Same & Worse Off \\
\hline \multirow[t]{5}{*}{0 to 20,000} & Fraction: Larger Tax Cut & 0.21 & 0.02 & 0.18 \\
\hline & Fraction: Same Tax Cut & 0.44 & 0.60 & 0.26 \\
\hline & Fraction: Smaller Tax Cut & 0.36 & 0.38 & 0.56 \\
\hline & Spending Fraction & $13.5 \%$ & $15.8 \%$ & $50.0 \%$ \\
\hline & Frequency & 88 & 145 & 30 \\
\hline \multirow[t]{5}{*}{20,001 to 35,000} & Fraction: Larger Tax Cut & 0.18 & 0.08 & 0.05 \\
\hline & Fraction: Same Tax Cut & 0.59 & 0.45 & 0.42 \\
\hline & Fraction: Smaller Tax Cut & 0.23 & 0.47 & 0.53 \\
\hline & Spending Fraction & $15.9 \%$ & $22.3 \%$ & $7.8 \%$ \\
\hline & Frequency & 94 & 141 & 19 \\
\hline \multirow[t]{5}{*}{35,001 to 50,000} & Fraction: Larger Tax Cut & 0.26 & 0.14 & 0.14 \\
\hline & Fraction: Same Tax Cut & 0.44 & 0.56 & 0.26 \\
\hline & Fraction: Smaller Tax Cut & 0.30 & 0.31 & 0.60 \\
\hline & Spending Fraction & $13.4 \%$ & $26.3 \%$ & $10.8 \%$ \\
\hline & Frequency & 98 & 103 & 30 \\
\hline \multirow[t]{5}{*}{50,001 to 75,000} & Fraction: Larger Tax Cut & 0.19 & 0.11 & 0.05 \\
\hline & Fraction: Same Tax Cut & 0.55 & 0.49 & 0.59 \\
\hline & Fraction: Smaller Tax Cut & 0.26 & 0.40 & 0.36 \\
\hline & Spending Fraction & $27.7 \%$ & $27.9 \%$ & $25.3 \%$ \\
\hline & Frequency & 112 & 113 & 22 \\
\hline \multirow[t]{5}{*}{ More than 75,000} & Fraction: Larger Tax Cut & 0.31 & 0.18 & 0.26 \\
\hline & Fraction: Same Tax Cut & 0.39 & 0.43 & 0.36 \\
\hline & Fraction: Smaller Tax Cut & 0.30 & 0.40 & 0.38 \\
\hline & Spending Fraction & $23.8 \%$ & $26.5 \%$ & $17.2 \%$ \\
\hline & Frequency & 122 & 143 & 35 \\
\hline
\end{tabular}

Note-The table show expectations of size of future tax cuts and fraction spending the rebate by income groups and expectations of future financial condition. The first three rows of each cell show the fraction expecting a larger, same, or lower tax cut. The fourth row shows the fraction spending the rebate. The fifth row in each cell gives the frequency of the cell. See also note to Table 2. 
Table 7-Plans for Spending Rebate

\begin{tabular}{lcc}
\hline & $\begin{array}{c}(\mathrm{A}) \\
\text { Frequency }\end{array}$ & $\begin{array}{c}(\mathrm{B}) \\
\text { Number }\end{array}$ \\
\hline Spend rebate on what & & \\
Particular Item & $39.8 \%$ & 100 \\
Day-to-Day Expense & $60.2 \%$ & 151 \\
& & \\
When spend rebate & & \\
Already Spent & $54.6 \%$ & 133 \\
Within Month & $21.6 \%$ & 52 \\
Within 2 Months & $7.0 \%$ & 17 \\
By End of Year & $13.6 \%$ & 33 \\
Next Year & $3.2 \%$ & 8
\end{tabular}

Note: Tabulations based on weighted responses with "don't know" and "refused" excluded. Column A gives the frequency of response. Column $B$ gives number of responses. 
Table 8-Spend or Save Rebate?

A. Response by Timing of Survey Response or Receipt of Rebate

\begin{tabular}{|c|c|c|c|c|c|c|c|}
\hline & $(\mathrm{A})$ & (B) & $(\mathrm{C})$ & (D) & $(\mathrm{E})$ & $(F)$ & $(\mathrm{G})$ \\
\hline & Frequency & $\begin{array}{l}\text { Spend } \\
\text { Rebate }\end{array}$ & $\begin{array}{c}\text { Save } \\
\text { Rebate }\end{array}$ & $\begin{array}{c}\text { Pay Debt } \\
\text { With Rebate }\end{array}$ & $\begin{array}{c}\text { Will Not } \\
\text { Get Rebate }\end{array}$ & $\begin{array}{c}\text { Spend } \\
\text { Percentage }\end{array}$ & $p$-value \\
\hline \multicolumn{8}{|l|}{ Timing of Survey Response } \\
\hline Before attack & $49.6 \%$ & 106 & 198 & 272 & 117 & $18.4 \%$ & 0.005 \\
\hline After attack & $50.4 \%$ & 150 & 178 & 271 & 106 & $25.1 \%$ & \\
\hline \multicolumn{8}{|l|}{ When Received Rebate } \\
\hline Not yet & $40.8 \%$ & 78 & 161 & 236 & NA & $16.4 \%$ & \\
\hline Within last week & $7.7 \%$ & 26 & 27 & 36 & NA & $29.2 \%$ & 0.001 \\
\hline 1-4 weeks ago & $24.0 \%$ & 63 & 91 & 126 & NA & $22.5 \%$ & \\
\hline More than 4 weeks ago & $27.5 \%$ & 89 & 92 & 140 & NA & $27.6 \%$ & \\
\hline
\end{tabular}

B. Response by Timing of Survey versus Receipt of Rebate

\begin{tabular}{|c|c|c|}
\hline & $(\mathrm{A})$ & (B) \\
\hline & \multicolumn{2}{|c|}{ Received Rebate Yet } \\
\hline & No & Yes \\
\hline \multicolumn{3}{|c|}{ Timing of Survey Response } \\
\hline \multirow[t]{2}{*}{ August } & $17.3 \%$ & $22.6 \%$ \\
\hline & 296 & 100 \\
\hline \multirow[t]{2}{*}{ September } & $13.4 \%$ & $22.3 \%$ \\
\hline & 145 & 266 \\
\hline \multirow[t]{2}{*}{ October } & $19.4 \%$ & $29.2 \%$ \\
\hline & 54 & 344 \\
\hline
\end{tabular}

Note: In panel B, the first number is cells are percentage of respondents spending the rebate and the second number is the frequency. See also note to Table 2. 
August September October Final Pooled Results

Updated Nov 13, 2001

Table 9-Regression Analysis of Spending Rebate:
Timing of Survey and Timing of Receipt of Rebate

\begin{tabular}{|c|c|c|c|c|c|c|}
\hline & (A) & (B) & (C) & (D) & (E) & $(F)$ \\
\hline Timing of survey: & & & & & & \\
\hline After attack & $\begin{array}{l}0.067 \\
(0.025)^{\star *}\end{array}$ & & $\begin{array}{c}0.019 \\
(0.041)\end{array}$ & $\begin{array}{c}0.012 \\
(0.041)\end{array}$ & & \\
\hline September & & $\begin{array}{c}0.006 \\
(0.029)\end{array}$ & $\begin{array}{l}-0.003 \\
(0.035)\end{array}$ & $\begin{array}{l}-0.029 \\
(0.037)\end{array}$ & $\begin{array}{l}-0.025 \\
(0.031)\end{array}$ & \\
\hline October & & $\begin{array}{l}0.092 \\
(0.032)^{\star *}\end{array}$ & $\begin{array}{c}0.073 \\
(0.052)\end{array}$ & $\begin{array}{c}0.036 \\
(0.056)\end{array}$ & $\begin{array}{c}0.045 \\
(0.036)\end{array}$ & \\
\hline $\begin{array}{l}\text { Received Rebate: } \\
\text { Last week }\end{array}$ & & & & $\begin{array}{c}0.130 \\
(0.053)^{*}\end{array}$ & & \\
\hline 1-4 weeks ago & & & & $\begin{array}{c}0.050 \\
(0.035)\end{array}$ & & \\
\hline More than 4 weeks ago & & & & $\begin{array}{c}0.084 \\
(0.037)^{*}\end{array}$ & & \\
\hline Received Rebate & & & & & $\begin{array}{l}0.079 \\
(0.028)^{* *}\end{array}$ & $\begin{array}{c}0.093 \\
(0.025)^{\star *}\end{array}$ \\
\hline Constant & $\begin{array}{c}0.184 \\
(0.017)^{\star *}\end{array}$ & $\begin{array}{c}0.185 \\
(0.021)^{* *}\end{array}$ & $\begin{array}{l}0.185 \\
(0.021)^{\star *}\end{array}$ & $\begin{array}{l}0.166 \\
(0.022)^{\star *}\end{array}$ & $\begin{array}{l}0.166 \\
(0.022)^{\star *}\end{array}$ & $\begin{array}{l}0.164 \\
(0.018)^{* *}\end{array}$ \\
\hline Observations & 1200 & 1200 & 1200 & 1187 & 1187 & 1187 \\
\hline R-squared & 0.01 & 0.01 & 0.01 & 0.02 & 0.02 & 0.01 \\
\hline
\end{tabular}

Note: Estimates are linear probability regression with the dependent variable equal to one if the tax rebate is spent and zero if it is saved or used to repay debt. Estimates are based on weighted data. Heteroskedastic-consistent standard errors are in parentheses. A * indicates significant at the $5 \%$ level; a ${ }^{* *}$ indicates significant at the $1 \%$ level. See Appendix Table 1 for definitions and means of dependent variables. 
Table 10-Regression Analysis of Spending Rebate: Covariates

\begin{tabular}{|c|c|c|c|}
\hline \multirow{2}{*}{\multicolumn{2}{|c|}{ Log income }} & (A) & (B) \\
\hline & & 0.028 & 0.023 \\
\hline \multirow[t]{6}{*}{ Stock } & 1 to 15,000 & -0.072 & -0.072 \\
\hline & & (0.039) & $(0.038)$ \\
\hline & 15,001 to 50,000 & $\begin{array}{l}-0.031 \\
(0.042)\end{array}$ & $\begin{array}{l}-0.035 \\
(0.041)\end{array}$ \\
\hline & 50,001 to 100,000 & $\begin{array}{c}0.028 \\
(0.050)\end{array}$ & $\begin{array}{c}0.024 \\
(0.050)\end{array}$ \\
\hline & 100,000 to 250,000 & $\begin{array}{c}0.054 \\
(0.047)\end{array}$ & $\begin{array}{c}0.051 \\
(0.046)\end{array}$ \\
\hline & More than 250,000 & $\begin{array}{c}0.030 \\
(0.057)\end{array}$ & $\begin{array}{c}0.028 \\
(0.056)\end{array}$ \\
\hline \multicolumn{2}{|c|}{ Married } & $\begin{array}{c}0.043 \\
(0.032)\end{array}$ & $\begin{array}{c}0.040 \\
(0.030)\end{array}$ \\
\hline \multicolumn{2}{|c|}{ Children } & $\begin{array}{l}-0.018 \\
(0.032)\end{array}$ & \\
\hline \multicolumn{2}{|c|}{ Age 30 to 39} & $\begin{array}{c}0.053 \\
(0.042)\end{array}$ & $\begin{array}{c}0.050 \\
(0.041)\end{array}$ \\
\hline \multicolumn{2}{|c|}{ Age 40 to 49} & $\begin{array}{c}0.078 \\
(0.043)\end{array}$ & $\begin{array}{c}0.077 \\
(0.042)\end{array}$ \\
\hline \multicolumn{2}{|c|}{ Age 50 to 64} & $\begin{array}{c}0.028 \\
(0.042)\end{array}$ & $\begin{array}{c}0.034 \\
(0.041)\end{array}$ \\
\hline \multicolumn{2}{|c|}{ Age 65 and over } & $\begin{array}{c}0.124 \\
(0.054)^{*}\end{array}$ & $\begin{array}{c}0.132 \\
(0.053)^{*}\end{array}$ \\
\hline \multicolumn{2}{|c|}{ High School Graduate } & $\begin{array}{c}0.007 \\
(0.065)\end{array}$ & \\
\hline \multicolumn{2}{|c|}{ Some College } & $\begin{array}{l}-0.003 \\
(0.065)\end{array}$ & \\
\hline \multicolumn{2}{|c|}{ College Graduate and beyond } & $\begin{array}{l}-0.020 \\
(0.065)\end{array}$ & \\
\hline \multicolumn{2}{|c|}{ September } & $\begin{array}{l}-0.023 \\
(0.032)\end{array}$ & $\begin{array}{l}-0.024 \\
(0.032)\end{array}$ \\
\hline \multicolumn{2}{|c|}{ October } & $\begin{array}{c}0.043 \\
(0.038)\end{array}$ & $\begin{array}{c}0.042 \\
(0.038)\end{array}$ \\
\hline \multicolumn{2}{|c|}{ Received Rebate } & $\begin{array}{c}0.075 \\
(0.030)^{*}\end{array}$ & $\begin{array}{c}0.075 \\
(0.030)^{*}\end{array}$ \\
\hline \multicolumn{2}{|c|}{ Constant } & $\begin{array}{l}-0.202 \\
(0.233)\end{array}$ & $\begin{array}{l}-0.163 \\
(0.225)\end{array}$ \\
\hline \multirow{2}{*}{\multicolumn{2}{|c|}{ Observations }} & 1059 & 1059 \\
\hline R-squared & & 0.04 & 0.04 \\
\hline
\end{tabular}

Note: See Table 9. 
Table 11-Regression Analysis of Spending Rebate: Financial Condition

\begin{tabular}{|c|c|c|c|c|c|}
\hline \multirow{2}{*}{\multicolumn{2}{|c|}{ Log income }} & $(\mathrm{A})$ & (B) & $(\mathrm{C})$ & (D) \\
\hline & & $\begin{array}{l}0.018 \\
0.022)\end{array}$ & $\begin{array}{l}0.026 \\
(0.023)\end{array}$ & $\begin{array}{l}0.021 \\
(0.023)\end{array}$ & $\begin{array}{l}0.023 \\
(0.022)\end{array}$ \\
\hline \multirow[t]{5}{*}{ Stock } & 1 to 15,000 & $\begin{array}{l}-0.071 \\
(0.039)\end{array}$ & $\begin{array}{l}-0.077 \\
(0.038)^{*}\end{array}$ & $\begin{array}{l}-0.078 \\
(0.039)^{*}\end{array}$ & $\begin{array}{l}-0.073 \\
(0.038)\end{array}$ \\
\hline & 15,001 to 50,000 & $\begin{array}{l}-0.037 \\
(0.041)\end{array}$ & $\begin{array}{l}-0.034 \\
(0.042)\end{array}$ & $\begin{array}{l}-0.037 \\
(0.042)\end{array}$ & $\begin{array}{l}-0.029 \\
(0.041)\end{array}$ \\
\hline & 50,001 to 100,000 & $\begin{array}{l}0.024 \\
(0.050)\end{array}$ & $\begin{array}{l}0.025 \\
(0.050)\end{array}$ & $\begin{array}{l}0.025 \\
(0.051)\end{array}$ & $\begin{array}{c}0.024 \\
(0.050)\end{array}$ \\
\hline & 100,000 to 250,000 & $\begin{array}{c}0.053 \\
(0.046)\end{array}$ & $\begin{array}{c}0.054 \\
(0.047)\end{array}$ & $\begin{array}{c}0.056 \\
(0.047)\end{array}$ & $\begin{array}{c}0.056 \\
(0.046)\end{array}$ \\
\hline & More than 250,000 & $\begin{array}{c}0.037 \\
(0.056)\end{array}$ & $\begin{array}{c}0.021 \\
(0.057)\end{array}$ & $\begin{array}{c}0.030 \\
(0.057)\end{array}$ & $\begin{array}{c}0.034 \\
(0.056)\end{array}$ \\
\hline Married & 30 & $\begin{array}{c}0.040 \\
(0.030)\end{array}$ & $\begin{array}{c}0.036 \\
(0.031)\end{array}$ & $\begin{array}{c}0.037 \\
(0.031)\end{array}$ & $\begin{array}{c}0.045 \\
(0.030)\end{array}$ \\
\hline \multicolumn{2}{|c|}{ Age 30 to 39} & $\begin{array}{c}0.055 \\
(0.041)\end{array}$ & $\begin{array}{c}0.050 \\
(0.042)\end{array}$ & $\begin{array}{c}0.055 \\
(0.041)\end{array}$ & $\begin{array}{c}0.045 \\
(0.041)\end{array}$ \\
\hline \multicolumn{2}{|c|}{ Age 40 to 49} & $\begin{array}{l}0.084 \\
(0.042)^{*}\end{array}$ & $\begin{array}{c}0.080 \\
(0.043)\end{array}$ & $\begin{array}{l}0.088 \\
(0.043)^{*}\end{array}$ & $\begin{array}{c}0.072 \\
(0.042)\end{array}$ \\
\hline \multicolumn{2}{|c|}{ Age 50 to 64} & $\begin{array}{c}0.039 \\
(0.041)\end{array}$ & $\begin{array}{c}0.039 \\
(0.042)\end{array}$ & $\begin{array}{c}0.045 \\
(0.042)\end{array}$ & $\begin{array}{l}0.033 \\
(0.041)\end{array}$ \\
\hline \multicolumn{2}{|c|}{ Age 65 and over } & $\begin{array}{c}0.134 \\
(0.055)^{*}\end{array}$ & $\begin{array}{c}0.142 \\
(0.057)^{*}\end{array}$ & $\begin{array}{c}0.146 \\
(0.058)^{*}\end{array}$ & $\begin{array}{c}0.130 \\
(0.055)^{*}\end{array}$ \\
\hline \multicolumn{2}{|c|}{ September } & $\begin{array}{l}-0.019 \\
(0.032)\end{array}$ & $\begin{array}{l}-0.024 \\
(0.033)\end{array}$ & $\begin{array}{l}-0.018 \\
(0.033)\end{array}$ & $\begin{array}{l}-0.026 \\
(0.033)\end{array}$ \\
\hline \multicolumn{2}{|c|}{ October } & $\begin{array}{c}0.048 \\
(0.038)\end{array}$ & $\begin{array}{c}0.039 \\
(0.039)\end{array}$ & $\begin{array}{c}0.045 \\
(0.038)\end{array}$ & $\begin{array}{c}0.037 \\
(0.038)\end{array}$ \\
\hline \multicolumn{2}{|c|}{ Received Rebate } & $\begin{array}{c}0.071 \\
(0.030)^{*}\end{array}$ & $\begin{array}{c}0.076 \\
(0.030)^{*}\end{array}$ & $\begin{array}{c}0.072 \\
(0.030)^{*}\end{array}$ & $\begin{array}{c}0.073 \\
(0.030)^{*}\end{array}$ \\
\hline \multicolumn{6}{|c|}{ Financial condition compared to last year: } \\
\hline \multicolumn{2}{|c|}{ Better now } & $\begin{array}{c}0.071 \\
(0.030)^{*}\end{array}$ & & $\begin{array}{l}0.072 \\
(0.031)^{*}\end{array}$ & \\
\hline \multicolumn{2}{|c|}{ Same } & $\begin{array}{c}0.065 \\
(0.036)\end{array}$ & & $\begin{array}{c}0.069 \\
(0.037)\end{array}$ & \\
\hline \multicolumn{6}{|c|}{ Financial condition expected next year: } \\
\hline \multicolumn{2}{|c|}{ Better off } & & $\begin{array}{c}0.023 \\
(0.046)\end{array}$ & $\begin{array}{c}0.021 \\
(0.046)\end{array}$ & \\
\hline \multicolumn{2}{|c|}{ Same } & & $\begin{array}{c}0.045 \\
(0.045)\end{array}$ & $\begin{array}{c}0.036 \\
(0.046)\end{array}$ & \\
\hline \multicolumn{6}{|c|}{ Expected income: } \\
\hline \multicolumn{2}{|c|}{ Higher } & & & & $\begin{array}{c}0.057 \\
(0.041)\end{array}$ \\
\hline \multicolumn{2}{|c|}{ Same } & & & & $\begin{array}{c}0.079 \\
(0.047)\end{array}$ \\
\hline \multicolumn{2}{|c|}{ Constant } & $\begin{array}{l}-0.166 \\
(0.229)\end{array}$ & $\begin{array}{l}-0.223 \\
(0.243)\end{array}$ & $\begin{array}{l}-0.225 \\
(0.242)\end{array}$ & $\begin{array}{l}-0.218 \\
(0.234)\end{array}$ \\
\hline \multirow{2}{*}{\multicolumn{2}{|c|}{$\begin{array}{l}\text { Observations } \\
\text { R-squared }\end{array}$}} & 1056 & 1030 & 1028 & 1051 \\
\hline & & 0.05 & 0.05 & 0.05 & 0.05 \\
\hline
\end{tabular}

Note: See Table 9. 
Table 12-Regression Analysis of Spending Rebate: Budgeting

\begin{tabular}{|c|c|c|c|c|}
\hline & & (A) & (B) & (C) \\
\hline \multicolumn{2}{|c|}{ Log income } & $\begin{array}{c}0.027 \\
(0.022)\end{array}$ & $\begin{array}{c}0.037 \\
(0.027)\end{array}$ & $\begin{array}{c}0.019 \\
(0.022)\end{array}$ \\
\hline \multirow[t]{5}{*}{ Stock } & 1 to 15,000 & $\begin{array}{l}-0.074 \\
(0.038)\end{array}$ & $\begin{array}{l}-0.045 \\
(0.049)\end{array}$ & $\begin{array}{l}-0.071 \\
(0.039)\end{array}$ \\
\hline & 15,001 to 50,000 & $\begin{array}{l}-0.037 \\
(0.041)\end{array}$ & $\begin{array}{l}-0.042 \\
(0.048)\end{array}$ & $\begin{array}{l}-0.040 \\
(0.041)\end{array}$ \\
\hline & 50,001 to 100,000 & $\begin{array}{c}0.027 \\
(0.050)\end{array}$ & $\begin{array}{c}0.085 \\
(0.065)\end{array}$ & $\begin{array}{c}0.016 \\
(0.049)\end{array}$ \\
\hline & 100,000 to 250,000 & $\begin{array}{c}0.048 \\
(0.046)\end{array}$ & $\begin{array}{c}0.040 \\
(0.057)\end{array}$ & $\begin{array}{c}0.039 \\
(0.046)\end{array}$ \\
\hline & More than 250,000 & $\begin{array}{c}0.028 \\
(0.057)\end{array}$ & $\begin{array}{l}-0.020 \\
(0.072)\end{array}$ & $\begin{array}{c}0.016 \\
(0.057)\end{array}$ \\
\hline \multicolumn{2}{|c|}{ Married } & $\begin{array}{c}0.038 \\
(0.030)\end{array}$ & $\begin{array}{c}0.036 \\
(0.038)\end{array}$ & $\begin{array}{c}0.035 \\
(0.030)\end{array}$ \\
\hline \multicolumn{2}{|c|}{ Age 30 to 39} & $\begin{array}{c}0.045 \\
(0.041)\end{array}$ & $\begin{array}{c}0.045 \\
(0.051)\end{array}$ & $\begin{array}{c}0.052 \\
(0.041)\end{array}$ \\
\hline \multicolumn{2}{|c|}{ Age 40 to 49} & $\begin{array}{c}0.075 \\
(0.043)\end{array}$ & $\begin{array}{c}0.065 \\
(0.052)\end{array}$ & $\begin{array}{l}0.086 \\
(0.043)^{*}\end{array}$ \\
\hline \multicolumn{2}{|c|}{ Age 50 to 64} & $\begin{array}{c}0.031 \\
(0.041)\end{array}$ & $\begin{array}{c}0.016 \\
(0.051)\end{array}$ & $\begin{array}{c}0.041 \\
(0.041)\end{array}$ \\
\hline \multicolumn{2}{|c|}{ Age 65 and over } & $\begin{array}{c}0.135 \\
(0.053)^{*}\end{array}$ & $\begin{array}{l}0.190 \\
(0.071)^{\star *}\end{array}$ & $\begin{array}{c}0.128 \\
(0.054)^{*}\end{array}$ \\
\hline \multicolumn{2}{|c|}{ September } & $\begin{array}{l}-0.022 \\
(0.032)\end{array}$ & $\begin{array}{l}-0.008 \\
(0.042)\end{array}$ & $\begin{array}{l}-0.024 \\
(0.033)\end{array}$ \\
\hline \multicolumn{2}{|c|}{ October } & $\begin{array}{c}0.043 \\
(0.038)\end{array}$ & $\begin{array}{c}0.047 \\
(0.047)\end{array}$ & $\begin{array}{c}0.034 \\
(0.038)\end{array}$ \\
\hline \multicolumn{2}{|c|}{ Received Rebate } & $\begin{array}{c}0.075 \\
(0.030)^{*}\end{array}$ & $\begin{array}{l}0.098 \\
(0.036)^{\star *}\end{array}$ & $\begin{array}{c}0.072 \\
(0.030)^{\star}\end{array}$ \\
\hline \multicolumn{2}{|c|}{ Has budget } & $\begin{array}{c}0.034 \\
(0.028)\end{array}$ & & \\
\hline \multicolumn{2}{|c|}{ Targets spending } & & $\begin{array}{c}0.045 \\
(0.035)\end{array}$ & \\
\hline \multicolumn{2}{|c|}{ Targets saving } & & $\begin{array}{c}0.014 \\
(0.035)\end{array}$ & \\
\hline \multicolumn{2}{|c|}{ Targets debt payment } & & $\begin{array}{l}-0.036 \\
(0.035)\end{array}$ & \\
\hline \multicolumn{2}{|c|}{ Use savings for unexpected expense } & & & $\begin{array}{c}0.054 \\
(0.032)\end{array}$ \\
\hline \multicolumn{2}{|c|}{ Use credit for unexpected expense } & & & $\begin{array}{l}-0.034 \\
(0.036)\end{array}$ \\
\hline \multicolumn{2}{|c|}{ Constant } & $\begin{array}{l}-0.218 \\
(0.228)\end{array}$ & $\begin{array}{l}-0.329 \\
(0.268)\end{array}$ & $\begin{array}{l}-0.128 \\
(0.227)\end{array}$ \\
\hline \multirow{2}{*}{\multicolumn{2}{|c|}{$\begin{array}{l}\text { Observations } \\
\text { R-squared }\end{array}$}} & 1057 & 701 & 1043 \\
\hline & & 0.05 & 0.06 & 0.05 \\
\hline
\end{tabular}

Note: See Table 9. For equations with budget targets, "targets other" is the excluded category. 
Table 13—Regression Analysis of Spending Rebate: Outlook for Economy and Policy

\begin{tabular}{|c|c|c|c|c|c|}
\hline \multirow{3}{*}{\multicolumn{2}{|c|}{ Log income }} & $(\mathrm{A})$ & (B) & $\begin{array}{l}(\mathrm{C}) \\
\end{array}$ & (D) \\
\hline & & 0.018 & 0.017 & 0.025 & 0.014 \\
\hline & & $(0.023)$ & $(0.022)$ & $(0.022)$ & $(0.024)$ \\
\hline \multirow[t]{5}{*}{ Stock } & 1 to 15,000 & $\begin{array}{l}-0.080 \\
(0.037)^{*}\end{array}$ & $\begin{array}{l}-0.073 \\
(0.038)\end{array}$ & $\begin{array}{l}-0.071 \\
(0.039)\end{array}$ & $\begin{array}{l}-0.067 \\
(0.040)\end{array}$ \\
\hline & 15,001 to 50,000 & $\begin{array}{l}-0.027 \\
(0.042)\end{array}$ & $\begin{array}{l}-0.019 \\
(0.042)\end{array}$ & $\begin{array}{l}-0.033 \\
(0.041)\end{array}$ & $\begin{array}{l}-0.036 \\
(0.041)\end{array}$ \\
\hline & 50,001 to 100,000 & $\begin{array}{c}0.033 \\
(0.050)\end{array}$ & $\begin{array}{c}0.031 \\
(0.050)\end{array}$ & $\begin{array}{c}0.017 \\
(0.049)\end{array}$ & $\begin{array}{c}0.021 \\
(0.050)\end{array}$ \\
\hline & 100,000 to 250,000 & $\begin{array}{c}0.076 \\
(0.049)\end{array}$ & $\begin{array}{c}0.063 \\
(0.046)\end{array}$ & $\begin{array}{c}0.055 \\
(0.047)\end{array}$ & $\begin{array}{c}0.064 \\
(0.047)\end{array}$ \\
\hline & More than 250,000 & $\begin{array}{c}0.031 \\
(0.058)\end{array}$ & $\begin{array}{c}0.032 \\
(0.057)\end{array}$ & $\begin{array}{c}0.017 \\
(0.056)\end{array}$ & $\begin{array}{c}0.044 \\
(0.058)\end{array}$ \\
\hline \multicolumn{2}{|c|}{ Married } & $\begin{array}{c}0.037 \\
(0.031)\end{array}$ & $\begin{array}{c}0.036 \\
(0.030)\end{array}$ & $\begin{array}{c}0.042 \\
(0.030)\end{array}$ & $\begin{array}{c}0.044 \\
(0.031)\end{array}$ \\
\hline \multicolumn{2}{|c|}{ Age 30 to 39} & $\begin{array}{c}0.043 \\
(0.042)\end{array}$ & $\begin{array}{c}0.044 \\
(0.041)\end{array}$ & $\begin{array}{c}0.035 \\
(0.041)\end{array}$ & $\begin{array}{c}0.051 \\
(0.042)\end{array}$ \\
\hline \multicolumn{2}{|c|}{ Age 40 to 49} & $\begin{array}{c}0.084 \\
(0.044)\end{array}$ & $\begin{array}{c}0.072 \\
(0.042)\end{array}$ & $\begin{array}{c}0.074 \\
(0.043)\end{array}$ & $\begin{array}{c}0.075 \\
(0.043)\end{array}$ \\
\hline \multicolumn{2}{|c|}{ Age 50 to 64} & $\begin{array}{c}0.039 \\
(0.042)\end{array}$ & $\begin{array}{c}0.029 \\
(0.041)\end{array}$ & $\begin{array}{c}0.034 \\
(0.041)\end{array}$ & $\begin{array}{c}0.027 \\
(0.042)\end{array}$ \\
\hline \multicolumn{2}{|c|}{ Age 65 and over } & $\begin{array}{c}0.140 \\
(0.055)^{*}\end{array}$ & $\begin{array}{l}0.139 \\
(0.054)^{\star *}\end{array}$ & $\begin{array}{c}0.125 \\
(0.054)^{*}\end{array}$ & $\begin{array}{c}0.127 \\
(0.056)^{*}\end{array}$ \\
\hline \multicolumn{2}{|c|}{ September } & $\begin{array}{l}-0.014 \\
(0.033)\end{array}$ & $\begin{array}{l}-0.025 \\
(0.033)\end{array}$ & $\begin{array}{l}-0.033 \\
(0.033)\end{array}$ & $\begin{array}{l}-0.026 \\
(0.033)\end{array}$ \\
\hline \multicolumn{2}{|c|}{ October } & $\begin{array}{c}0.041 \\
(0.039)\end{array}$ & $\begin{array}{c}0.034 \\
(0.038)\end{array}$ & $\begin{array}{c}0.036 \\
(0.038)\end{array}$ & $\begin{array}{c}0.045 \\
(0.039)\end{array}$ \\
\hline \multicolumn{2}{|c|}{ Received Rebate } & $\begin{array}{c}0.070 \\
(0.031)^{*}\end{array}$ & $\begin{array}{c}0.072 \\
(0.030)^{*}\end{array}$ & $\begin{array}{c}0.076 \\
(0.030)^{*}\end{array}$ & $\begin{array}{c}0.066 \\
(0.030)^{x}\end{array}$ \\
\hline \multicolumn{2}{|c|}{ Future tax cuts larger } & $\begin{array}{c}0.035 \\
(0.039)\end{array}$ & & & \\
\hline \multicolumn{2}{|c|}{ Future tax cuts smaller } & $\begin{array}{c}0.018 \\
(0.030)\end{array}$ & & & \\
\hline \multicolumn{2}{|c|}{ Tax cuts improve own situation } & & $\begin{array}{c}0.068 \\
(0.031)^{*}\end{array}$ & & \\
\hline \multicolumn{2}{|c|}{ Tax cuts worsen own situation } & & $\begin{array}{c}0.092 \\
(0.073)\end{array}$ & & \\
\hline \multicolumn{2}{|c|}{ Tax cuts improve economy } & & & $\begin{array}{c}0.068 \\
(0.031)^{*}\end{array}$ & \\
\hline \multicolumn{2}{|c|}{ Tax cuts worsen economy } & & & $\begin{array}{c}0.098 \\
(0.051)\end{array}$ & \\
\hline \multicolumn{2}{|c|}{ Tax cuts decrease government spending } & & & & $\begin{array}{c}0.012 \\
(0.033)\end{array}$ \\
\hline \multicolumn{2}{|c|}{ Tax cuts increase government spending } & & & & $\begin{array}{c}0.016 \\
(0.035)\end{array}$ \\
\hline \multicolumn{2}{|c|}{ Constant } & $\begin{array}{c}-0.132 \\
(0.228)\end{array}$ & $\begin{array}{l}-0.116 \\
(0.227)\end{array}$ & $\begin{array}{l}-0.200 \\
(0.226)\end{array}$ & $\begin{array}{l}-0.067 \\
(0.248)\end{array}$ \\
\hline \multirow{2}{*}{\multicolumn{2}{|c|}{$\begin{array}{l}\text { Observations } \\
\text { R-squared }\end{array}$}} & 983 & 1042 & 1040 & 1015 \\
\hline & & 0.05 & 0.05 & 0.05 & 0.04 \\
\hline
\end{tabular}

See note to Table 9. 


\section{Appendix Table 1-Means of Covariates in Regressions}

\begin{tabular}{lc}
\hline \hline Independent variables & mean \\
\hline Log income & 10.79 \\
Married & .61 \\
Children & .39 \\
Age 30 to 39 & .25 \\
Age 40 to 49 & .24 \\
Age 50 to 64 & .24 \\
Age 65 and over & .13 \\
High School Graduate & .23 \\
Some College & .24 \\
College Graduate and beyond & .47 \\
September & .34 \\
October & .33 \\
Received Rebate & .60 \\
Observations & 1059 \\
\hline
\end{tabular}

Note-Means of covariates in estimates from Table 9, Column (A). Log income is log of household income. All variables are zero, one dummies: Married is 1 if the respondent is married. Children is 1 if there are children under 18 in the household. The age and education dummies are 1 if the respondent falls in the respective age and education ranges. The College Graduate and beyond categories includes those with more than 16 years of schooling. September and October are dummies for survey response in those months (August excluded category). Received rebate is 1 for households who had received the rebate at the time of the survey. 